\title{
Investigating the Smuts: Common Cues, Signaling Pathways, and the Role of MAT in Dimorphic Switching and Pathogenesis
}

\author{
Teeratas Kijpornyongpan ${ }^{+}(\mathbb{D}$ and M. Catherine Aime * \\ Department of Botany and Plant Pathology, Purdue University, West Lafayette, IN 47907, USA; \\ Teeratas.Kijpornyongpan@nrel.gov or tkijporn@purdue.edu \\ * Correspondence: maime@purdue.edu \\ + Current affiliation: National Bioenergy Center, National Renewable Energy Laboratory, Golden, \\ CO 80401, USA.
}

Received: 15 November 2020; Accepted: 14 December 2020; Published: 16 December 2020

\begin{abstract}
The corn smut fungus Ustilago maydis serves as a model species for studying fungal dimorphism and its role in phytopathogenic development. The pathogen has two growth phases: a saprobic yeast phase and a pathogenic filamentous phase. Dimorphic transition of $U$. maydis involves complex processes of signal perception, mating, and cellular reprogramming. Recent advances in improvement of reference genomes, high-throughput sequencing and molecular genetics studies have been expanding research in this field. However, the biology of other non-model species is frequently overlooked. This leads to uncertainty regarding how much of what is known in $U$. maydis is applicable to other dimorphic fungi. In this review, we will discuss dimorphic fungi in the aspects of physiology, reproductive biology, genomics, and molecular genetics. We also perform comparative analyses between $U$. maydis and other fungi in Ustilaginomycotina, the subphylum to which $U$. maydis belongs. We find that lipid/hydrophobicity is a potential common cue for dimorphic transition in plant-associated dimorphic fungi. However, genomic profiles alone are not adequate to explain dimorphism across different fungi.
\end{abstract}

Keywords: smut fungi; mating locus; Tween40; molecular signaling pathway; filamentous growth; yeast growth; morphological transition; comparative genomics

\section{Introduction}

Fungi is one of the most diverse eukaryotic kingdoms of which members have colonized nearly every habitat and evolved multiple nutritional modes and strategies for survival and reproduction. In terms of growth and development, there are two common types of growth in fungi: filamentous growth and yeast growth. Most described fungi have an ability to grow as tube-like filamentous cells termed 'hypha', which serve as a basic unit for complex multicellular structures such as vegetative mycelia, dormant structures like sclerotia, asexual spore-bearing structures, and the sometimes complex fruiting bodies that produce sexual spores [1,2]. Some species, however, can survive, grow, and reproduce as a solitary cell, termed 'yeast' [3]. A subset of fungi has evolved the ability to grow both as unicellular yeasts and as multicellular hyphae (or, occasionally, as chains of incomplete bud cells termed pseudohyphae). These are called the 'dimorphic fungi'.

Dimorphic fungi are predominantly found in Dikarya (a subkingdom including Ascomycota and Basidiomycota), although this phenomenon was originally described in the zygomycete genus Mucor ([4], Table 1). In Ascomycota, the best known of these are the 'thermally dimorphic fungi' - many of which are also known as 'black fungi' or 'black yeasts' [5]. These fungi can be pathogenic to 
humans, and temperature serves as a stimulus for morphological transition between the hyphal and yeast phases [6]. Despite this shared character, thermally dimorphic fungi are a polyphyletic group found in three different ascomycete classes-Sordariomycetes, Eurotiomycetes and Dothideomycetes (Table 1). Another well-known dimorphic fungus is Candida albicans (Saccharomycotina), which is an opportunistic human pathogen. Dimorphic plant pathogenic fungi appear to differ from the thermally dimorphic fungi in not requiring temperature changes to induce different growth phases. Examples of dimorphic plant pathogens include the ascomycetes Taphrina deformans (Taphrinomycotina), which causes peach leaf curl disease, Ophiostoma ulmi and O. novo-ulmi (Sordariomycetes), which cause Dutch elm disease and Zymoseptoria tritici (Dothideomycetes), which causes Septoria leaf blotch on wheat. Recent studies have shown that the early-diverging basidiomycete lineages Pucciniomycotina, Ustilaginomycotina and Tremellomycetes also comprise many dimorphic fungi [7-9]. However, in most instances these receive less attention as most are neither economically important nor detrimentally harmful to humans. The best studied of the basidiomycete dimorphic fungi is the model species Ustilago maydis, which causes a disease in corn known as corn smut (Ustilaginomycotina, Basidiomycota).

Ustilago maydis is a saprobic yeast in its haploid stage, which can be grown in axenic cultures but is rarely detected in nature [7]. To undergo morphological transition, $U$. maydis requires mating from a genetically compatible partner, determined by mating (MAT) loci, as well as host signal perception [10]. After that, the pathogen transitions to its dikaryotic (having two haploid nuclei per cell) phase that includes both a switch to filamentous growth and a trophic switch from saprobic to pathogenic in planta. The pathogen ends its infectious cycle by transforming its hyphal masses into teliospores, which serve as both the dormant and reproductive propagules. Finally, meiosis occurs within teliospores that germinate to produce yeast cells for a new cycle.

Recent research has focused on how U. maydis undergoes dimorphic transition and becomes pathogenic to a host. However, studies in other non-model dimorphic fungi are limited and very few genetic tools/resources are available for these. The development of advancing technologies such as high-throughput sequencing and more rapid methods for genome assembly and annotation can provide reference data for non-model species to facilitate comparative studies [11-13].

Here, we provide a comprehensive review, combined with data from pilot studies, of (1) physiological factors affecting fungal dimorphism, (2) the mating system contributing to fungal dimorphism, and (3) underlying molecular mechanisms of dimorphic transition. With the extensive body of data available for $U$. maydis as a base, we make multiple comparative analyses between the $U$. maydis system and that of other phytopathogenic dimorphic fungi, drawn from preliminary physiological and genomic studies of other Ustilaginomycotina species. For the purpose of this review, we inclusively consider any fungus that has both a yeast phase and a filamentous phase, consisting of either true hyphae or pseudohyphae, as a dimorphic fungus.

\section{Physiological Aspect of Fungal Dimorphism}

\subsection{External Factors Affecting Fungal Dimorphism}

Because most dimorphic fungi can be grown in axenic culture, there is a body of physiological studies to provide an overview of known triggers in dimorphic transition (Table 1). Nitrogen starvation is widely known to trigger yeast-to-filamentous growth in several species such as Saccharomyces cerevisiae, Schizosaccharomyces pombe, Candida albicans, Cryptococcus neoformans, Ustilago maydis and Zymoseptoria tritici [14-19]. In contrast, Trichosporon cutaneum and Yarrowia lipolytica represent exceptions in which high nitrogen promotes filamentous growth $[20,21]$. The type of nitrogen source also affects transition in several dimorphic species [20,22-26]. The effect of carbon source on fungal dimorphism has been reported, but less frequently. For instance, fermentable hexoses can promote yeast growth in several Mucor species [27], while S. cerevisiae undergoes invasive filamentous growth when cultured in the absence of fermentable sugars [28]. The sugar derivative $\mathrm{N}$-acetyl glucosamine serves as an 
elicitor for filamentous growth of C. albicans, Y. lipolytica, Histoplasma capsulatum and Blastomyces dermatidis $[16,29,30]$.

Other environmental factors can also impact dimorphic switching. Acidic $\mathrm{pH}$ induces filamentous growth in two basidiomycete dimorphic fungi-U. maydis and T. cutaneum [20,31]; Pseudohyphal growth is induced in Tremella fusiformis under $\mathrm{pH}$ 5-7 [25]; Y. lipolytica and C. albicans form hyphae under alkaline $\mathrm{pH}$ [24,32]. It has long been known that anaerobic condition, or high $\mathrm{CO}_{2}$ tension, triggers yeast growth of several Mucor species [27]. More recently, these have been found to promote hyphal growth in at least two ascomycete dimorphic fungi, C. albicans and Y. lipolytica [16,24]. Interestingly, there is a single report showing an effect of $\mathrm{Zn}^{2+}$ on promoting filamentous growth in Aureobasidium pullulans [33]. Finally, physical properties such as temperature, media solidity and agitation can affect growth form in culture of some dimorphic fungi $[20,34,35]$.

Table 1. Examples of dimorphic fungi, life history strategies, and environmental cues for morphological transition.

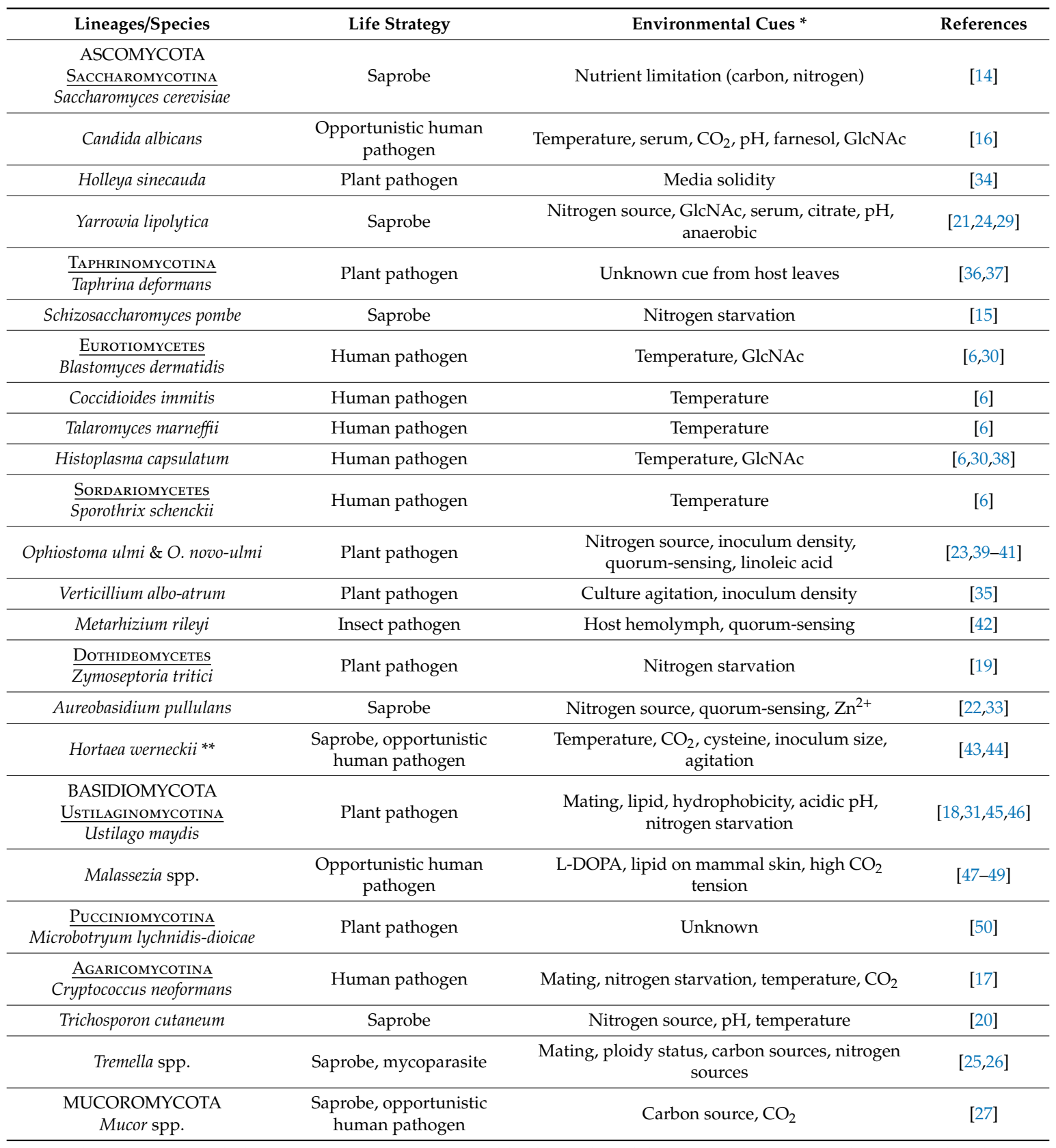

* GlcNAc $=$ N-acetyl glucosamine, L-DOPA $=$ L-3,4-dihydroxyphenylalanine. ${ }^{*}$ The genus is also reported in the

literature as Cladosporium and Exophiala. 
In addition to environmental cues, dimorphic pathogens also utilize signals from their hosts to undergo morphological transition as well as to initiate infection and colonization. Temperature serves as a primary factor for triggering dimorphic transition in many human pathogenic fungi (Table 1). Most of these are adapted to grow as yeasts at $37^{\circ} \mathrm{C}$ (human body temperature), and as hyphae in a cooler environment $[6,17,44]$. High $\mathrm{CO}_{2}$ tension, which is presumably found in human tissues, can also promote yeast growth in some dimorphic pathogens that cause systemic infection $[17,27,44]$. Conversely, human body temperature, high $\mathrm{CO}_{2}$ and blood serum are factors that promote filamentous growth in C. albicans [16]. The commensal and opportunistic fungus Malassezia is likely to require signals on mammal skins for filamentous growth, which is enhanced under a microaerophilic environment $[49,51]$. While signals involved in fungal dimorphism have been extensively studied in human pathogens, very little data exist for switching mechanisms in phytopathogenic fungi. In the well-studied dimorphic plant pathogen $U$. maydis, acid $\mathrm{pH}$, lipid and hydrophobicity have been demonstrated to promote filamentous growth [31,46,52]. Linoleic acid can also induce hyphal growth in the Dutch-elm disease pathogen O. novo-ulmi [41]. These cues are commonly found on the plant host surface [53], suggesting that the pathogens perceive the host for dimorphic transition. The peach leaf curl pathogen Taphrina deformans has filamentous growth only when it colonizes a host, possibly after perceiving an unknown signal [37].

\subsection{Comparative Physiological Studies in Ustilaginomycotina}

We conducted a pilot experiment in $U$. maydis and closely related species in Ustilaginomycotina to determine what signals might serve as a common cue for plant-associated dimorphic fungi [12]. By varying several types of carbon sources, we found that the lipid-mimic Tween 40 triggers dimorphic transition in most dimorphic Ustilaginomycotina species (Figures 1 and 2). These confirm findings from prior work demonstrating that plant oils, fatty acids and Tween 40 promote filamentous growth of $U$. maydis [54]. More recent studies also reveal the effect of hydroxy-fatty acids and hydrophobic surfaces on promoting hyphal growth of the $U$. maydis solopathogenic strain SG200 [46]. Of the Ustilaginomycotina species we sampled, those exhibiting filamentous growth under Tween 40 as a carbon source are all phylloplane fungi (i.e., found on plant leaf surfaces) - U. maydis (Ustma), Jaminaea rosea (Jamro), Meira miltonrushii (Meimi), Violaceomyces palustris (Viopa) and Tilletiopsis washingtonensis (Tilwa) [55-58]. It is possible that they utilize lipids/hydrophobicity as signals upon arrival on a host surface. Hydrophobicity and lipid compounds are also involved in morphogenesis in other plant pathogenic fungi, such as appressoria formation in the rice blast fungus Magnaporthe oryzae and the powdery mildew fungus Blumeria graminis [59,60] and yeast-to-hyphal transition in O. ulmi and O. novo-ulmi $[40,41]$. Because the abovementioned fungi interact with a wide variety of plant host species, lipids and hydrophobicity may be a commonly utilized signal to trigger dimorphic transition in plant-associated fungi in general.

However, Tween40 does not promote hyphal growth in other studied species such as the smut fungus Testicularia cyperi and the phylloplane fungus Moesziomyces aphidis (Figures 1 and 2) and it is evident that different fungi sense different host signal molecules. For example, Magnaporthe oryzae can sense surface hydrophobicity, cutin monomers or leaf waxes to trigger appressoria formation [59]. As the environment on plant surfaces is rich in lipids but poor in nitrogen compounds [53], some plant-associated fungi such as S. cerevisiae and Z. tritici may perceive nitrogen starvation as a signal that they have arrived on host surfaces $[19,61]$. Other dimorphic fungi may perceive other biomolecules inside plant hosts. For instance, we found that pectin, a common component of plant cell walls, triggers yeast-to-hyphal transition in two dimorphic fungi-V. palustris and T. cyperi ([12]; Figures 1 and 2), the first such study to implicate pectin in phase transitions. More intriguingly, our study shows temperature as a trigger for dimorphic transition in some Ustilaginomycotina species such as U. maydis, Moesziomyces aphidis, T. cyperi and V. palustris ([12], Figures 1 and 2). However, none of the energy-source carbohydrates tested in our study significantly promotes hyphal growth in our studied species. Finally, we found three Ustilaginomycotina species with consistent monomorphic growth, regardless 
of treatment. Acaromyces ingoldii has constitutively hyphal growth, whereas Pseudomicrostroma glucosiphilum and Meira sp. MCA4637 have constitutively yeast growth ([12]; Figures 1 and 2).

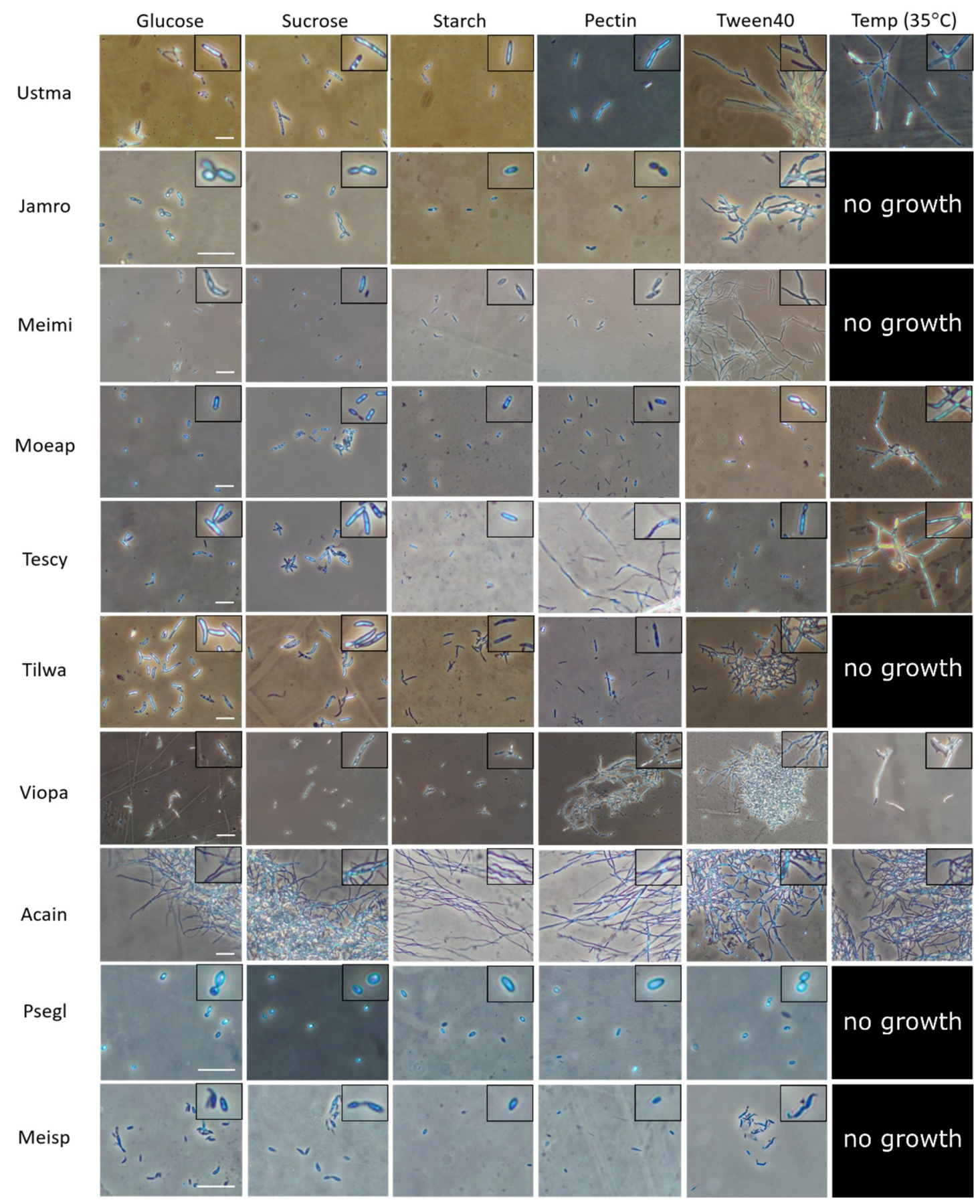

Figure 1. Effects of carbon sources and temperature on fungal dimorphism of Ustilaginomycotina. Cell morphologies of ten Ustilaginomycotina species were observed after treatment under different carbon sources (glucose, sucrose, starch, pectin, Tween 40$)$ and high temperature $\left(35^{\circ} \mathrm{C}\right)$ with glucose as a carbon source. Most treatments were incubated at $25{ }^{\circ} \mathrm{C}$ for 5 days. Fungal cultures were observed under phase contrast microscopy. An inlay photomicrograph in each cell is magnified up to 1.5 times to better visualize cell morphology. Species abbreviations are as follows: Ustma, Ustilago maydis; Jamro, Jaminaea rosea; Meimi, Meira miltonrushii; Moeap, Moesziomyces aphidis; Tescy, Testicularia cyperi; Tilwa, Tilletiopsis washingtonensis; Viopa, Violaceomyces palustris; Acain, Acaromyces ingoldii; Psegl, Pseudomicrostroma glucosiphilum, Meisp, Meira sp. MCA4637. Bars: $20 \mu \mathrm{m}$. 


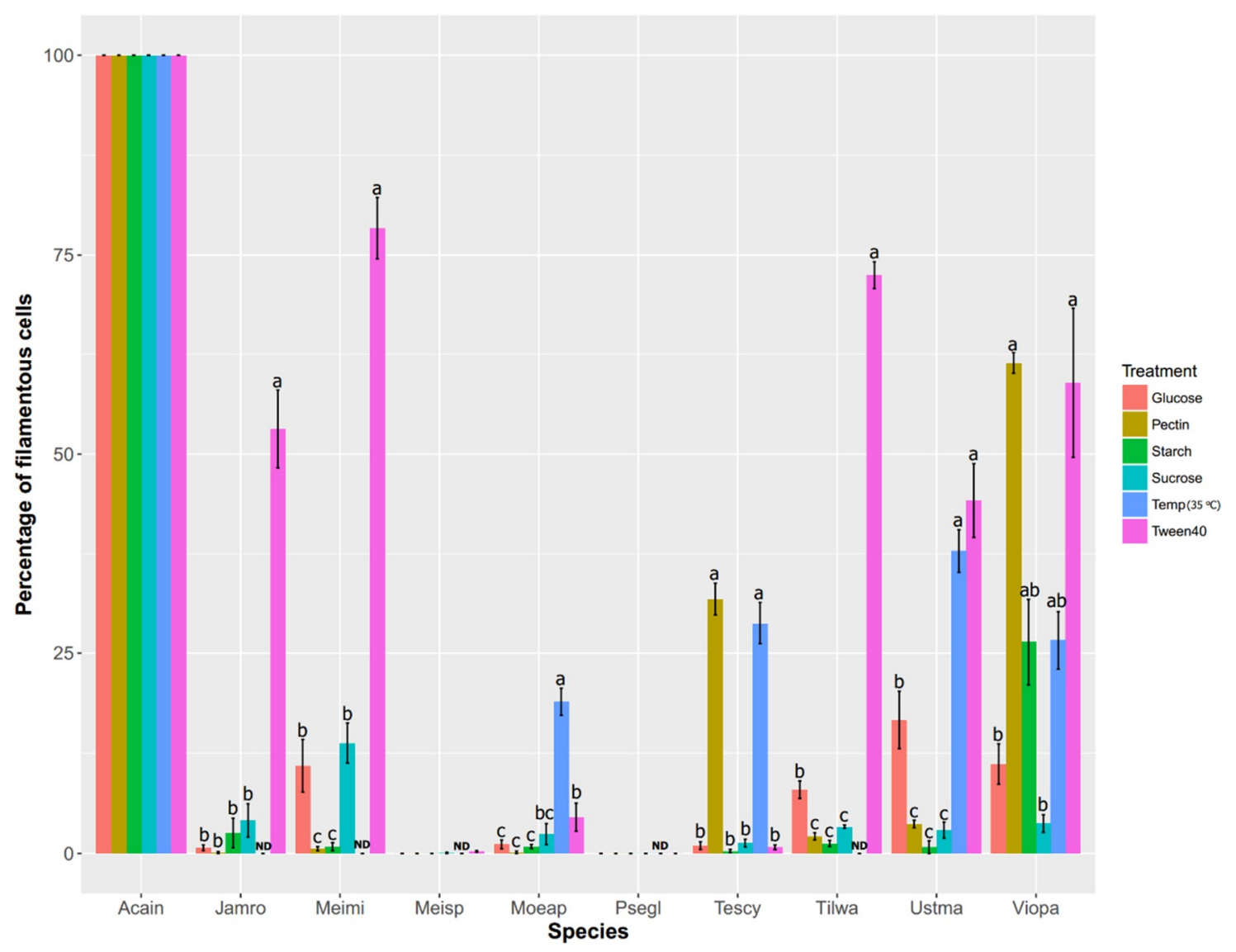

Figure 2. Growth form quantification of ten Ustilaginomycotina species supplied with different carbon sources (red, gold, green, aqua and pink) and high temperature (blue). This figure is a statistical representation of data from Figure 1. The growth form is reported as percentages of filamentous cells. One-way analysis of variance (ANOVA) was used to test differences among treatments for each species. Letters indicate statistical groups inferred from the Tukey HSD post-hoc test, with ' $a$ ' as the highest value, ' $b$ ' as an intermediate value and ' $c$ ' as the lowest value. ND: no data, meaning that fungi do not grow in those conditions. Species abbreviations are as indicated in the Figure 1 legend.

\section{Mating and Fungal Dimorphism}

\subsection{Cellular Communication in Dimorphic Fungi}

Intercellular communication is another critical factor for determining growth phases in many dimorphic fungi. Inoculum density plays a major role in dimorphism of several ascomycete species such as Ophiostoma ulmi and O. novo-ulmi, Verticillium albo-atrum, Metarhizium rileyi and Aureobasidium pullulans [22,35,39], suggesting quorum-sensing activity in these fungi. Farnesol, as a renowned quorum-sensing molecule, is secreted by C. albicans to suppress its filamentous growth and biofilm formation [16]. Other quorum-sensing molecules involved in fungal growth and development are discussed in a recent review [62]. Although quorum-sensing is poorly known in basidiomycete fungi, mating is associated with dimorphism in many species. Hyphal growth is often found in the post-mating dikaryotic stage of dimorphic fungi in Pucciniomycotina, Ustilaginomycotina and Tremellomycetes [63]. These include two model species: the human pathogenic fungus Cryptococcus neoformans [17] and the corn smut fungus $U$. maydis [64]. Here we focus on the plant pathogen $U$. maydis; a review of the mating system of $C$. neoformans and its role in filamentous growth can be found elsewhere [16,64]. 


\subsection{Mating (MAT) Loci in U. maydis}

In smut fungi such as $U$. maydis, the mating process is critical for dimorphic transition from yeast to filamentous growth, as well as for switching to a pathogenic phase for host infection. This has been demonstrated through MAT deletion studies in U. maydis [64-66], Sporisorium reilianum [67], and S. scitamineum [68]. There are two MAT loci in smut fungi: MAT $a$ and MAT $b$. The MAT $a$ locus comprises a pheromone precursor gene $(M f a)$ and a pheromone receptor gene (Pra). An expressed pheromone precursor protein is cleaved and then coupled with a farnesyl group to make a functional lipopeptide pheromone [69]. Then, the released pheromone binds to a pheromone receptor from another yeast cell that has a different MAT $a$ allele. This binding leads to the pheromone response, cell cycle arrest at the G2 stage, and conjugation tube formation [10]. Reciprocal pheromone perception of two mating-compatible yeast cells results in conjugation tube formation and cytoplasmic fusion to become dikaryotic. The MAT $b$ locus comprises genes encoding homeodomain transcription factors $b E$ and $b W$. These transcription factors become active once $b E$ from one $M A T b$ allele heterodimerizes with $b W$ from another MAT $b$ allele, and vice-versa. The $\mathrm{bE} / \mathrm{bW}$ heterodimer then regulates downstream genes that are involved in filamentous growth and pathogenic development. However, a cell cycle does not resume until the dikaryotic fungus perceives a signal from a plant host and successfully penetrates plant tissues [10]. In a few rare cases, some smut fungi can undergo pathogenic development without prior mating, termed solopathogens. Solopathogenic strains can originate either from diploid strains [70,71], or via genetic modification to artificially generate a single haploid strain with compatible $b E$ and $b W$ genes that can form a self-heterodimer [72].

In order to be genetically compatible for mating, both haploid yeast cells need to have different alleles at both the MAT $a$ and $b$ loci. When both MAT loci are unlinked, a number of mating types are possible as different combinations of the MAT $a$ alleles and MAT $b$ alleles. A fertilized diploid zygote can bear offspring with four possible mating types, termed a 'tetrapolar' mating system. In $U$. maydis and S. reilianum, there are up to three alleles of the MAT $a$ locus and up to 25 alleles of the MAT $b$ locus [69]. This allelic diversity would increase the chances for outcrossing with other individuals within a population $[69,73]$. Other smut fungi such as $U$. hordei and S. scitamineum have linked MAT $a$ and $b$ loci. Therefore, a fertilized diploid zygote can bear offspring with only two possible mating types, termed a 'bipolar' mating system. The bipolar mating system decreases the odds for outcrossing compatibility due to dependent assortment of both MAT loci, while promoting selfing/inbreeding as there is a $50 \%$ chance of compatibility with offspring in the same cohort, but only a $25 \%$ chance for sibling mating in the tetrapolar mating system [69,73]. A recent study of Kellner et al. [74] revealed that there are three conserved alleles in the MAT a locus among smut fungi in Ustilaginales, regardless of whether the MAT arrangement is bipolar or tetrapolar. The allelic conservation of the MAT $a$ locus is also demonstrated by interspecific pheromone response [74]. Therefore, we postulate that genetic diversity at the MAT $b$ locus is a primary determinant for reproductive isolation across different species, as well as for increasing intraspecific outcrossing compatibility in the tetrapolar mating system.

\subsection{Comparative MAT Loci Analyses in Ustilaginomycotina}

We sampled sixteen representative genomes in Ustilaginomycotina to examine how the arrangement of the MAT loci is conserved in this subphylum ([13,75-81]; Figure 3). First, we found that most studied species have the tetrapolar mating system, except Testicularia cyperi and Malassezia globosa, which are bipolar, and Exobasidium vaccinii, which is strictly bipolar (i.e., genes in the MAT $b$ locus are located right next to genes in the MAT a locus). We found that gene arrangement near the MAT $a$ and $b$ loci is conserved in Ustilaginales, including U. maydis, Pseudozyma hubeiensis, S. reilianum, P. antartctica, and T. cyperi. In Violaceomyces palustris, a few neighboring genes located next to the $b W / b E$ genes are syntenic to those in other examined Ustilaginales species. A gene encoding a DEAD-box helicase is proximal to the $b W / b E$ genes for most studied Ustilaginomycotina species, except Jaminaea rosea, Pseudomicrostroma glucosiphilum, Acaromyces ingoldii, E. vaccinii, Meira miltonrushii and $V$. palustris. In addition, $\mathrm{bW}$ or bE protein sequences are truncated in Testicularia cyperi, Tilletiaria anomala, 
P. antartctica, M. globosa and M. sympodialis (Figure 3, Figures S1 and S2). As most of these species are found to be dimorphic, this truncation may only affect the mating process but not fungal dimorphism. The truncation of the $b E$ genes in Malassezia may explain why mating has never been observed for this fungus despite the presence of both the MAT $a$ and $b$ loci [69].

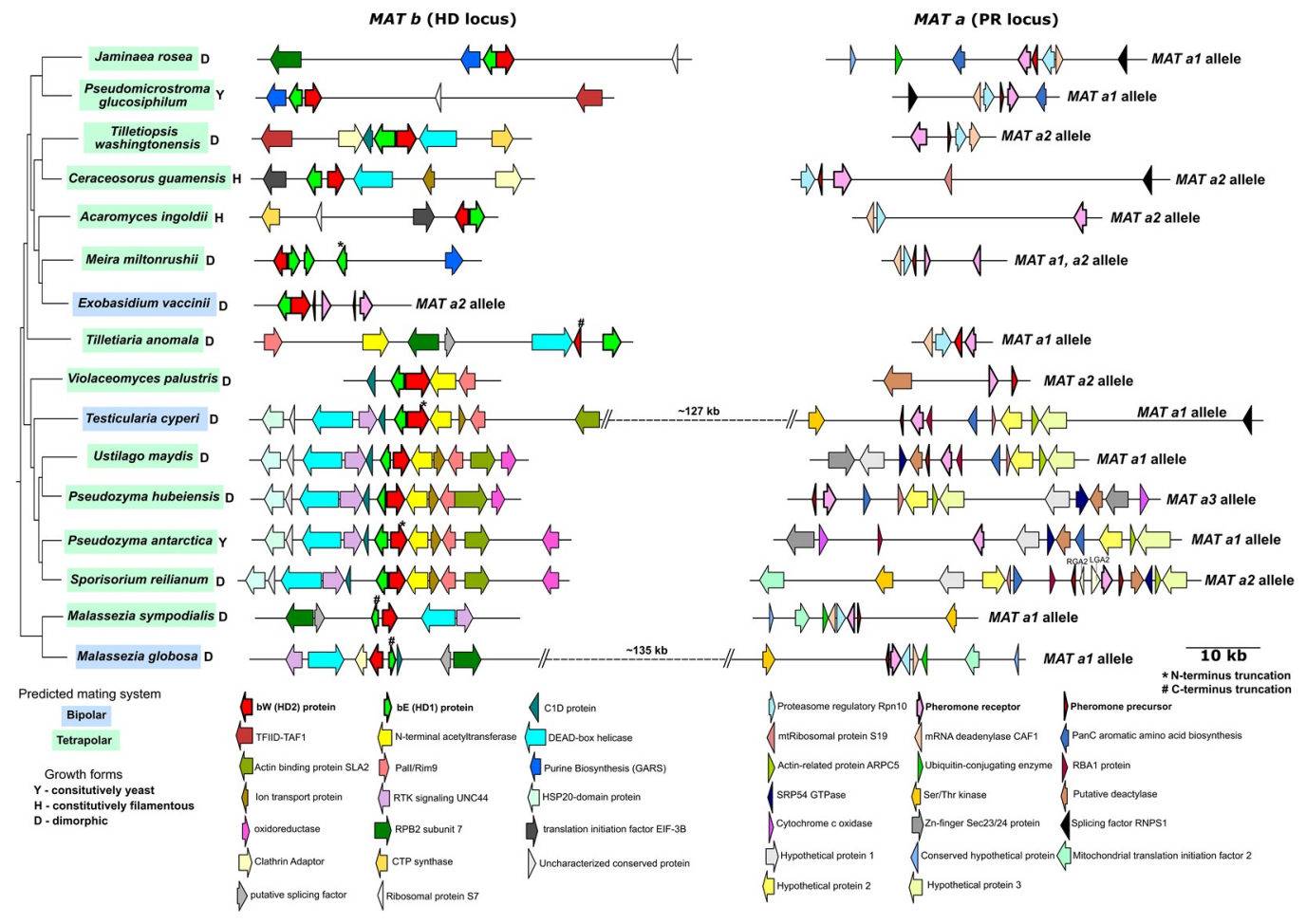

Figure 3. Comparative synteny of MAT loci in Ustilaginomycotina. Sixteen genomes of Ustilaginomycotina were incorporated in the analyses. Genes for pheromone receptor (Pra), bE and bW from Ustilago maydis were used as references to identify MAT loci in studied species. Gene synteny was examined within 20 kilobases upstream and downstream of the mating genes. Only genes that are syntenic in at least two species are shown. Gene orientation is indicated by arrowheads. Different arrowhead colors indicate different genes (see more details in the legend). Predicted mating system and growth form are indicated at each species' name. Allele type of MAT a locus is determined by the gene phylogeny of pheromone receptor genes (Figure S3).

For the MAT a locus, gene synteny is conserved across species in Ustilaginales (Figure 3). Although conservation in gene synteny in other Ustilaginomycotina species is not in evidence, two genes encoding the proteasome regulatory subunit Rpn10 and the mRNA deadenylase CAF1 are frequently linked to a pheromone receptor gene. A pheromone precursor gene is not found in A. ingoldii and P. antarctica. It is notable that $A$. ingoldii is a constitutively filamentous fungus. The gene phylogeny of pheromone receptor genes reveals that most sampled genomes possess either the MAT a1 or $a 2$ allele (Figure S3). Considering the low prevalence of the $a 3$ allele in Kellner et al. [74] and in our study, we hypothesize that the $a 3$ allele has recently emerged in Ustilaginales.

In contrast to the conservation found within Ustilaginales, our analyses show a remarkable diversification of MAT arrangement in Exobasidiales species, including A. ingoldii, E. vaccinii and M. miltonrushii. No pheromone precursor gene is identified in A. ingoldii; a strictly bipolar MAT arrangement with a duplicate of the pheromone precursor gene and the pheromone receptor gene is found in E. vaccinii; and a duplicate of the $b E$ gene and the pheromone receptor gene is found in both the MAT a and $b$ loci of M. miltonrushii (Figure 3). The duplication of the MAT genes serves as another strategy for increasing mating type compatibility, which is commonly found in mushroom-forming fungi [69]. In short, the arrangement of the MAT loci in Ustilaginomycotina is 
much more diversified than previously known and is dependent on data from non-model species to fully appreciate this. Nonetheless, organization of the mating system alone cannot explain diversity of fungal growth forms in Ustilaginomycotina. As mating and ploidy status are typically coupled with fungal dimorphism of many early-diverging basidiomycetes (Ustilaginomycotina, Pucciniomycotina and Tremellomycetes) [63], it is interesting to further investigate the molecular mechanism of this coupling, as well as what causes decoupling in monomorphic species.

\section{Molecular Mechanism Related to Fungal Dimorphism}

After signal perception, dimorphic fungi require an elaborate system of signal transduction, gene regulation and biomolecular localization for morphogenetic reprogramming. Upstream signaling pathways are the most intensively studied as they are widely conserved. In fungi, there are two major conserved pathways-the cAMP/Protein kinase A (PKA) pathway and the mitogen-activated kinase (MAPK) pathway $[82,83]$. In this review, we will provide a comprehensive overview of these signaling pathways, as well as any upstream and downstream molecular players, using $U$. maydis as a primary model (summarized in Figure 4).

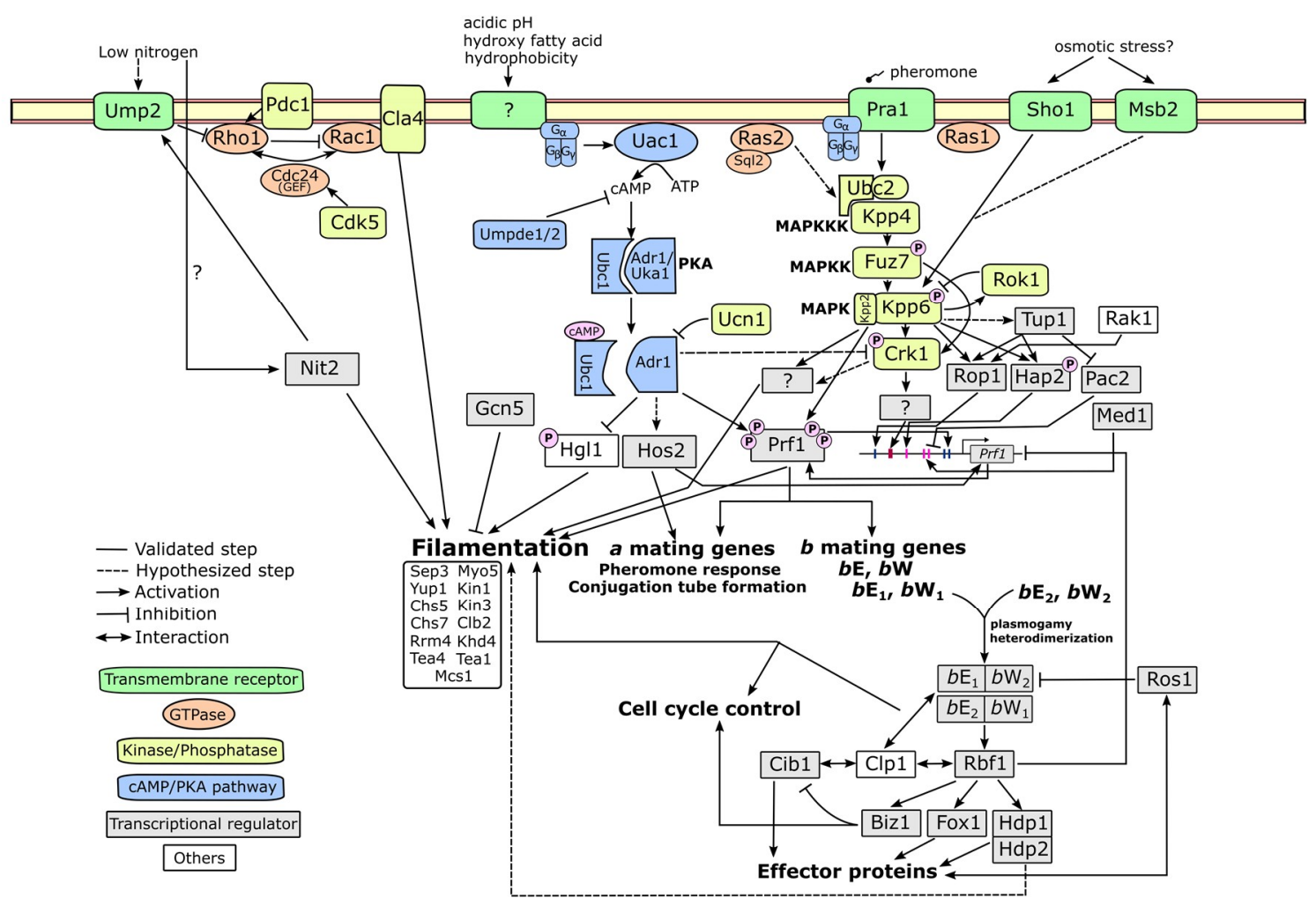

Figure 4. Overview of regulatory network for fungal dimorphism in U. maydis. The filamentous growth of $U$. maydis can be triggered through a few pathways: the cyclic-AMP/protein kinase A (cAMP/PKA) pathway, the mitogen-activated kinase (MAPK) pathway and the GTPase-mediated signaling pathway. These signal transductions trigger the alteration of transcriptional network that activates downstream effectors for morphogenesis. Details of molecular players in the figure can be found in Table S1.

\section{1. cAMP-PKA Pathway}

The cyclic-AMP/protein kinase A (cAMP-PKA) pathway is a well conserved signaling pathway across eukaryotic organisms [83]. The signaling initiates by the perception of an extracellular stimulus through a G protein-coupled receptor (GPCR). Once a ligand binds to the receptor, it interacts with a heterotrimeric $G$ protein complex, which is bound to the receptor, to activate a $G_{\alpha}$ subunit by incorporating a GTP molecule. Then, the active $G_{\alpha}$ subunit dissociates from the $G$ protein complex 
and subsequently activates an enzyme called adenylate cyclase. This enzyme catalyzes a conversion of ATP to $3^{\prime}, 5^{\prime}$ cyclic AMP (cAMP). The cAMP serves as a second messenger that amplifies a signal to downstream targets. One of the most important targets is protein kinase A (PKA), a hetero-tetrameric enzyme constituting two regulatory subunits and two catalytic subunits. The cAMP molecule binds to the regulatory subunits, causing them to release from the catalytic subunits. The PKA catalytic subunits can then phosphorylate many downstream proteins involved in various cellular responses. Finally, to provide a feedback control, a phosphodiesterase enzyme reduces an intracellular cAMP level by hydrolyzing a phosphodiester bond of cAMP, yielding AMP as a product.

Most components of the fungal cAMP-PKA pathway have been characterized in $U$. maydis. Regenfelder et al. [84] discovered four $\mathrm{G}_{\alpha}$ genes (Gpa1-Gpa4). Only Gpa3 shows a distinct phenotype from the others. The gpa1, gpa2 and gpa4 single mutants result in constitutively yeast growth and no response to pheromone, while the gpa3 mutant has a promoted filamentous growth but does not respond to a pheromone. A subsequent discovery of $\mathrm{G}_{\beta}$ (Bpp1) revealed a similar biological function to Gpa3 [85]. Uac1 was identified as an adenylate cyclase in U. maydis [86], for which the mutant has constitutively filamentous growth. Although a hetero-tetrameric structure of PKA is yet to be validated, the regulatory subunit $U b c 1$ and the catalytic subunits $A d r 1$ and $U k a 1$ have been identified. The $u b c 1$ mutant has a defect in filamentous growth in vitro [86], wherein it can colonize a host with hyphae but cannot undergo gall formation during the dikaryotic stage [87]. The adr1 mutant is constitutively filamentous in the haploid stage, but its pathogenicity is defective [88]. The other PKA catalytic subunit Uka1 does not show any significant effect on growth form and pathogenicity [88]. Finally, Agarwal et al. [89] recently characterized two phosphodiesterase genes Umpde1 and Umpde2. The deletion of umpde1 results in significantly reduced pathogenicity. While the umpde2 deletion mutant has a subtle effect on pathogenicity, its filamentous growth is strongly attenuated.

Overall, several molecular genetic studies have shown that the activation of the cAMP-PKA pathway promotes budding but reduces filamentous growth of $U$. maydis in vitro. This trend is confirmed by the addition of exogenous cAMP, which suppresses filamentous growth [86,90,91]. Meanwhile, filamentous growth is a consequence of the pathway activation in C. albicans and S. cerevisiae $[14,16]$. Defects of several components in the pathway often lead to hampered pathogenic development in $U$. maydis, suggesting that the cAMP-PKA pathway plays multiple roles in both cellular and pathogenic developments. In addition, dimorphic transition to filamentous growth alone is not sufficient for the switching from a saprobic phase to a pathogenic phase.

\subsection{MAPK Pathway}

The mitogen-activated protein kinase (MAPK) pathway is another extensively studied pathway in many eukaryotic systems. The pathway is activated through a sequential phosphorylation of Serine/Threonine/Tyrosine protein kinases, termed the MAPK cascade. There are three major groups of kinases in the MAPK cascade. A MAPK kinase kinase (MAPKKK) is activated by an upstream molecule such as a G-protein complex, a GTPase, or another kinase. The active MAPKKK phosphorylates a MAPK kinase (MAPKK) to enable its activity. After that, the MAPKK phosphorylates a MAPK to trigger its function as a final step in the cascade. Through phosphorylation, the activated MAPK can either stimulate or inhibit many downstream targets such as protein kinases, protein phosphatases, or transcription factors.

Components of the MAPK cascade have been described in $U$. maydis-Kpp4/Ubc4 as a MAPKKK gene [92,93], $\mathrm{Fuz7} / \mathrm{Ubc5}$ as a MAPKK gene [93,94] and Kpp2/Ubc3, Kpp6 and Crk1 as MAPK genes [95-98]. In addition, two genes directly involved in the cascade have been identified. Ubc2 encodes a pheromone-responsive adaptor protein that physically interacts with Kpp4 $[99,100]$. The other gene is a dual specificity phosphatase named Rok1, which negatively controls Kpp2 and Kpp6 through dephosphorylation [101].

Most known genes in the MAPK cascade of $U$. maydis are involved in pheromone response, conjugation tube formation, filamentous growth and pathogenic development [92-96,98,102]. 
An exception is Kpp6, of which the mutant has a normal morphogenesis but attenuated pathogenicity [97]. The Kpp4-Fuz7-Kpp2 MAPK cascade, corresponding to the Ste11-Ste7-Kss1 cascade in S. cerevisiae, affects dimorphic transition to filamentous growth [14,82]. A Kss1 paralog named Fus3, another downstream target of Ste7, has a separate role in S. cerevisiae mating [14]. However, in U. maydis the mating function is complemented by Kpp2, while its paralog Kpp6 has a single function in pathogenic development. Crk1 in U. maydis is another downstream target of Fuz7. Crk1 function, having a role in filamentous growth, mating and pathogenesis [98,102], can also be regulated through phosphorylation by Kpp2 and cAMP-mediated mechanism. Ime2, an ortholog of Crk1 in S. cerevisiae, is involved in pseudohyphal growth and meiotic progression via a cAMP-mediated pathway, although its upstream MAPK counterpart is still unknown [103]. These examples demonstrate the functional diversification of the MAPK pathway, as well as its potential crosstalk with the cAMP/PKA pathway. Saccharomyces cerevisiae has at least two other MAPK cascades-the Bck1-MKK1/2-Sit2 cascade involved in cell wall integrity and the Ste11/Ssk2/Ssk22-Pbs2-Hog1 cascade involved in high osmolarity response [82]. Interestingly, the osmotic sensor protein Sho1 in U. maydis can directly interact with Kpp6 to trigger appressorium formation on a hydrophobic surface [47], but whether Sho1 can interact with other components in the MAPK cascade remains unknown. Although recent comparative genomics reveals that almost all genes in other MAPK cascades have respective orthologs in $U$. maydis [82], none of these have been characterized. Therefore, it is interesting to investigate the other MAPK members to understand how they affect $U$. maydis growth and development.

The multidomain adaptor protein Ubc2 provides another example of functional diversification within a single molecule. Klosterman et al. [99] demonstrated that the SAM and RA domains at the $\mathrm{N}$-terminus region of $\mathrm{Ubc} 2$ are essential for $U$. maydis filamentous growth. They suggested a direct interaction of the SAM domain and Kpp4 as an underlying mechanism to activate the MAPK cascade. Two C-terminal SH3 domains of Ubc2 are dispensable for filamentous growth but required for pathogenesis [99]. Other proteins that interact with Ubc2 to trigger a different response are yet to be characterized. To summarize, the $U$. maydis MAPK pathway frequently has a coupled function for both filamentous growth and pathogenic development.

\subsection{Alternative Pathways}

In addition to the cAMP/PKA and MAPK pathways, GTPases are important signaling components for filamentous growth. A few families of GTPases have been described in $U$. maydis: Ras, Rac and Rho families. There are two described genes in the Ras family, Ras1 and Ras2. Ras2, acting upstream of the MAPK cascade, contributes to filamentous growth, mating response, and pathogenicity [104]. A subsequent study showed that the Ras2 function is activated by the guanyl nucleotide exchange factor Sql2 [105]. While Sql2 overexpression leads to constitutively filamentous growth, its deletion mutant has normal mating but adversely affects pathogenic development [105]. Ras1, less studied than Ras2, is only known to promote the expression of the pheromone gene [105]. Rac is another GTPase family known for polarized growth and cell wall expansion in U. maydis [106]. Overexpression of Rac1 causes $U$. maydis to display filamentous growth during the haploid stage, while overexpression of a hyperactivated form of Rac1 leads to an isotropic cell wall expansion and cell lethality [106]. Rac1 is activated by the guanyl nucleotide exchange factor Cdc24, but potentially inhibited by the Rho1 GTPase [107]. The only known downstream target of Rac1 is the PAK family kinase Cla4, which modulates polarized growth, cell separation and bud neck formation $[107,108]$. The cyclin-dependent kinase Cdk5 is also involved in cell polarity through modulating Cdc24 localization at a growing tip [109].

A few other signaling pathways related to fungal dimorphism have been reported in other dimorphic fungi. One is the two-component signaling system, which is thoroughly investigated in thermally dimorphic fungi [110]. The pathway is activated by signal perception through a hybrid histidine kinase, which induces phosphorylation of its response regulator at a histidine residue. After that, a histidine phosphotransfer protein mobilizes a phosphate group from the response 
regulator to a downstream target to activate/inhibit its function. Recent studies have shown that the class III hybrid histidine kinase plays a crucial role for dimorphic transition in Histoplasma capsulatum, Talaromyces marneffii and Blastomyces dermatidis [110]. Another pathway is the calcium signaling pathway. Upon a signal perception that leads to calcium ion influx, the elevated intracellular $\mathrm{Ca}^{2+}$ activates a calcium-binding protein called calmodulin. The $\mathrm{Ca}^{2+}$-bound calmodulin then interacts with other downstream proteins to trigger their functions. One of these is a Serine/Threonine protein phosphatase named calcineurin, which is found to control dimorphic transition in Mucor circinelloides and Paracoccidioides brasiliensis [111,112]. In M. circinelloides, calcineurin also contributes to spore size regulation, cell wall integrity and antifungal drug resistance [113]. A single study of $U$. maydis identifies the catalytic subunit of calcineurin Ucn1 as an antagonist of PKA [114].

\subsection{Upstream and Downstream Molecular Players}

Signal perception is one of the least studied areas in signal transduction for several reasons. One reason is that most receptors are transmembrane proteins, which are difficult for studying protein structures and interactions. Another concerns the exhaustive process of matching which ligands bind to which receptors. In $U$. maydis, the only confirmed ligand-receptor interaction is the lipopeptide pheromone and the seven-transmembrane pheromone receptor Pra1 [64]. The pheromone binding results in the activation of the MAPK cascade $[92,93,100]$. The high-affinity ammonium transporter Ump2 has recently been found to promote filamentous growth of $U$. maydis under low-ammonium conditions $[18,115]$. An interaction between Ump2 and Rho1 suggests a mechanism for filamentous growth via the Rho1-Rac1 signaling pathway. This suggests that Ump2 acts as a receptor for nitrogen starvation in addition to a transporter function. Sho1 and Msb2 are other two characterized transmembrane proteins that interact with the MAPK cascade [52]. These two proteins contribute to stress response and pseudohyphal growth in S. cerevisiae, whereas they play a role in appressoria formation but not filamentous growth in $U$. maydis [52]. Other signals, such as acidic $\mathrm{pH}$ and lipids, are involved in $U$. maydis filamentous growth. However, their corresponding receptors are yet to be discovered.

The pheromone response factor 1 (Prf1) is a master transcription factor that controls the mating process, filamentous growth and pathogenic development of $U$. maydis through the activation of genes in the MAT loci [10,45]. Many studies have investigated how Prf1 itself is regulated. The promoter region of Prf1 is relatively long with a length of at least 2 kilobases [116]. Prf1 can autoactivate itself by binding to its promoter to initiate transcription $[116,117]$. The promoter region is also subject to several transcription factors such as Rop1, Pac2, Hap2 and Med1 [116,118,119], and the regulation networks of these genes have been investigated $[118,120]$. A recent study reveals that the histone deacetylase Hos2 facilitates Prf1 transcription through unwinding the Prf1 open-reading frame region from histone molecules [121]. In addition to transcriptional control, Prf1 activity is also regulated via post-translational phosphorylation. Prf1 has multiple Serine/Threonine sites that are subject to phosphorylation by PKA and Kpp2 [122]. The PKA phosphorylation sites are required to induce gene expression in both MAT $a$ and $b$ loci, while the MAPK phosphorylation sites are essential for only MAT $b$ locus expression. Therefore, Prf1 represents one of a few known molecules that integrate signaling from different pathways and fine-tune downstream cellular responses.

Once the dikaryotic stage is formed, the $\mathrm{bE} / \mathrm{bW}$ heterodimer can transcriptionally regulate dozens of genes [123]. Heimel et al. [124] revealed that the bE/bW heterodimer may not directly regulate these downstream targets but does so via another master regulator called Rbf1. Several genes in pathogenesis and cell cycle regulation have been identified as targets of Rbf1 [124]. Therefore, the bE/bW regulatory cascade is crucial for filamentation and pathogenic development during the dikaryotic stage. After $U$. maydis fully colonizes a host plant, it undergoes a transition from vegetative growth to teliospore formation. A recent study has identified the WOPR family transcriptional factor Ros1 as a primary regulator for this switching [125]. One of Ros1 functions includes a feedback inhibition of the $\mathrm{bE} / \mathrm{bW}$ regulatory cascade. 
Although Prf1 serves as a central regulator for dimorphic transition, there are a few cases wherein $U$. maydis undergoes filamentous growth in a Prf1-independent manner. For instance, Lee and Kronstad [104] demonstrated that hyperactivated Ras2 can lead to a constitutively filamentous growth in prf1 mutant. The prf1 mutant can also form hyphae under induction by acidic pH or lipids [54,91]. Accordingly, there must be other downstream molecular players that have yet to be identified. Hgl1, a direct phosphorylation target of PKA that contributes to U. maydis filamentous growth [126], is so far not known to interact with Prf1. The GATA transcription factor Nit2 has recently been identified as a response factor for filamentous growth under nitrogen catabolite repression [127]. The nit2 deletion mutant does not alter expression of Prf1 and its upstream genes, suggesting that Nit2 may be either downstream or independent from Prf1. The histone acetyltransferase Gcn 5 also contributes to U. maydis dimorphism [128], but whether its function is Prf1-dependent remains unknown. To summarize, there are several alternative pathways that can induce dimorphic transition in $U$. maydis. However, the Prf1-mediated regulatory pathway is still crucial for pathogenic development of $U$. maydis as it leads to mating, dikaryotization and the establishment of the $\mathrm{bE} / \mathrm{bW}$ heterodimer, which subsequently turns on many downstream effectors and pathogenesis proteins.

After sequences of signal transduction and transcriptional regulation, target genes for cell structures and morphogenesis are ultimately activated. In U. maydis these include cytoskeletal motors such as the class V myosin gene Myo5 and the kinesin genes Kin1 and Kin3 [129-131]. Chitin synthases are another group of genes that affect fungal dimorphism. Weber et al. [132] found that the polar chitin synthases Chs 5 and Chs7 are required for conjugation tube formation, dikaryotic hyphae formation and pathogenicity, while the Myosin- $V$ chitin synthase Mcs1 only influences polarized growth once entrance to plant tissues has been achieved. In addition, cell division genes such as the B-type cyclin gene $C l b 2$, the nuclei distribution gene Clp1, and the septin gene Sep3 are involved in $U$. maydis filamentous growth [133-135]. Yup1 encodes an endosomal t-SNARE protein that is important for exocytosis and endocytosis; this is found to be critical for polarized growth [136]. The cell end markers Tea1 and Tea4, indicating a site for polarized growth, have been recently characterized in U. maydis [137,138]. Finally, the RNA-binding proteins Khd4 and Rrm4 have been demonstrated to control regular filamentous growth $[139,140]$. Rrm4 functions in long-distance mRNA transport so that transcripts involved in polarized growth can be expressed at a precise location $[10,141]$. Khd4 recognizes a certain sequence motif in RNA, suggesting a role in post-transcriptional regulation [140].

\subsection{Comparative Genomics of Fungal Dimorphism Genes in Ustilaginomycotina}

We performed comparative analyses to examine how genes involved in fungal dimorphism are conserved across different species in Ustilaginomycotina [13,75-79,81,142]. We found that genes in the cAMP/PKA pathway, the MAPK pathway, and the GTPase-mediated signaling are highly conserved in all studied species, except Jaminaea rosea, Malassezia globosa, Moesziomyces aphidis, Pseudozyma antarctica. Pseudozyma hubeiensis, Pseudomicrostroma glucosiphilum and Tilletiopsis washingtonensis, of which only 1-2 genes are absent (Table 2). The pheromone receptor gene Pra1 and the high-affinity ammonium transporter gene Ump2 are found in all species, suggesting conserved machinery for signal perception.

Surprisingly, Malassezia globosa and Moesziomyces aphidis are the two species with the greatest number of absent genes. Prf1 and its regulator genes such as Med1 and Rop1 are not found in the Malassezia globosa genome (Table 2). Moreover, a few downstream transcription factors of the bE/bW cascade-Biz1, Clp1 and Ros1-are also not found. This multiple gene loss may be associated with a drastic shift of Malassezia ecological niches from plant-associated fungi to animal-associated fungi [13]. In Moesziomyces aphidis, several polar tip-associated genes are lost from its genome, including the chitin synthase genes Chs7 and Mcs1, the RNA-binding protein gene Rrm4 and the cell end marker genes Tea1 and Tea4 (Table 2). Although Moesziomyces aphidis is able to display filamentous growth, hyphal production is limited compared to other dimorphic fungi [143,144]; our study. 
Table 2. Comparative genomics of dimorphism genes across sixteen Ustilaginomycotina species. Colors in the left column indicate: green, receptor genes; blue, genes in the cAMP/PKA pathway; yellow, genes in the MAPK pathway; red, genes in the GTPase-mediated signaling; white, other downstream genes. Details about genes in this table can be found in Figure 4 and Table S1. White and black cell colors indicate ortholog presence and absence, respectively. Species abbreviations are as follows: Acain, Acaromyces ingoldii; Cergu, Ceraceosorus guamensis; Exova, Exobasidium vaccinii; Jamro, Jaminaea rosea; Malgl, Malassezia globosa; Meimi, Meira miltonrushii; Moeap, Moesziomyces aphidis; Psean, Pseudozyma antarctica; Psehu, Pseudozyma hubeiensis; Psegl, Pseudomicrostroma glucosiphilum; Spore, Sporisorium reilianum; Tescy, Testicularia cyperi; Tilan, Tilletiaria anomala; Tilwa, Tilletiopsis washingtonensis; Ustma, Ustilago maydis; Viopa, Violaceomyces palustris.

\begin{tabular}{|c|c|c|c|c|c|c|c|c|c|c|c|c|c|c|c|c|c|}
\hline Gene Name & Ustma GeneID & Acain & Cergu & Exova & Jamro & Malg1 & Meimi & Moeap & Psean & Psehu & Psegl & Spore & Tescy & Tilan & Tilwa & Ustma & Viopa \\
\hline$M s b 2$ & UMAG_00480 & & & & & & & & & & & & & & & & \\
\hline Pra1 & UMAG_02383 & & & & & & & & & & & & & & & & \\
\hline Sho1 & UMAG_03156 & & & & & & & & & & & & & & & & \\
\hline Ump2 & UMAG_05889 & & & & & & & & & & & & & & & & \\
\hline Adr1 & UMAG_04456 & & & & & & & & & & & & & & & & \\
\hline Bpp1 & UMAG_00703 & & & & & & & & & & & & & & & & \\
\hline Gpa3 & UMAG_04474 & & & & & & & & & & & & & & & & \\
\hline Uac1 & UMAG_05232 & & & & & & & & & & & & & & & & \\
\hline Ubc1 & UMAG_00525 & & & & & & & & & & & & & & & & \\
\hline Uka1 & UMAG_11860 & & & & & & & & & & & & & & & & \\
\hline Umpde1 & UMAG_02531 & & & & & & & & & & & & & & & & \\
\hline Umpde2 & UMAG_10895 & & & & & & & & & & & & & & & & \\
\hline Crk1 & UMAG_11410 & & & & & & & & & & & & & & & & \\
\hline Fuz7/Ubc5 & UMAG_01514 & & & & & & & & & & & & & & & & \\
\hline Kpp2/Ubc3 & UMAG_03305 & & & & & & & & & & & & & & & & \\
\hline$K p p 4 / U b c 4$ & UMAG_04258 & & & & & & & & & & & & & & & & \\
\hline Kpp6 & UMAG_02331 & & & & & & & & & & & & & & & & \\
\hline Rok1 & UMAG_03701 & & & & & & & & & & & & & & & & \\
\hline Cla4 & UMAG_10145 & & & & & & & & & & & & & & & & \\
\hline$P d c 1$ & UMAG_01366 & & & & & & & & & & & & & & & & \\
\hline Ras1 & UMAG_01643 & & & & & & & & & & & & & & & & \\
\hline Ras2 & UMAG_03172 & & & & & & & & & & & & & & & & \\
\hline Rho1 & UMAG_05734 & & & & & & & & & & & & & & & & \\
\hline Sql2 & UMAG_10803 & & & & & & & & & & & & & & & & \\
\hline Biz1 & UMAG_02549 & & & & & & & & & & & & & & & & \\
\hline Chs5 & UMAG_10277 & & & & & & & & & & & & & & & & \\
\hline Chs7 & UMAG_05480 & & & & & & & & & & & & & & & & \\
\hline Cib1 & UMAG_11782 & & & & & & & & & & & & & & & & \\
\hline
\end{tabular}


Table 2. Cont.

\begin{tabular}{|c|c|c|c|c|c|c|c|c|c|c|c|c|c|c|c|c|c|}
\hline Gene Name & Ustma GeneID & Acain & Cergu & Exova & Jamro & Malg1 & Meimi & Moeap & Psean & Psehu & Psegl & Spore & Tescy & Tilan & Tilwa & Ustma & Viopa \\
\hline$C l b 2$ & UMAG_10279 & & & & & & & & & & & & & & & & \\
\hline Clp1 & UMAG_02438 & & & & & & & & & & & & & & & & \\
\hline Gcn5 & UMAG_10190 & & & & & & & & & & & & & & & & \\
\hline Hap2 & UMAG_01597 & & & & & & & & & & & & & & & & \\
\hline $\mathrm{Hgl1}$ & UMAG_11450 & & & & & & & & & & & & & & & & \\
\hline Hos2 & UMAG_11828 & & & & & & & & & & & & & & & & \\
\hline Khd4 & UMAG_03837 & & & & & & & & & & & & & & & & \\
\hline Kin1 & UMAG_04218 & & & & & & & & & & & & & & & & \\
\hline Kin3 & UMAG_06251 & & & & & & & & & & & & & & & & \\
\hline Med1 & UMAG_03588 & & & & & & & & & & & & & & & & \\
\hline Myo5 & UMAG_04555 & & & & & & & & & & & & & & & & \\
\hline Nit2 & UMAG_10417 & & & & & & & & & & & & & & & & \\
\hline Pac2 & UMAG_15096 & & & & & & & & & & & & & & & & \\
\hline Prf1 & UMAG_02713 & & & & & & & & & & & & & & & & \\
\hline Rac1 & UMAG_00774 & & & & & & & & & & & & & & & & \\
\hline Rak1 & UMAG_10146 & & & & & & & & & & & & & & & & \\
\hline Rbf1 & UMAG_03167 & & & & & & & & & & & & & & & & \\
\hline Rop1 & UMAG_12033 & & & & & & & & & & & & & & & & \\
\hline Rrm4 & UMAG_03494 & & & & & & & & & & & & & & & & \\
\hline Sep3 & UMAG_03449 & & & & & & & & & & & & & & & & \\
\hline Tea1 & UMAG_15019 & & & & & & & & & & & & & & & & \\
\hline Tea4 & UMAG_01012 & & & & & & & & & & & & & & & & \\
\hline Tup1 & UMAG_03280 & & & & & & & & & & & & & & & & \\
\hline Yup1 & UMAG_05406 & & & & & & & & & & & & & & & & \\
\hline
\end{tabular}




\section{Benefits of Fungal Dimorphism}

It has been hypothesized that dimorphic fungi utilize different growth forms to maximize fitness in different stages of their life cycle. For instance, filamentous growth in Saccharomyces cerevisiae, as a chain of elongated cells under nutrient-limited condition, is considered as a scavenging response to increase the chances of finding nutrients [14]. In many dimorphic human pathogens, the switch to unicellular yeast growth includes a drastic shift in cell wall composition to avoid recognition by host immune cells $[110,143]$. Recent reviews also suggested that the yeast form is beneficial for dissemination through the host bloodstream and respiratory tracts, and for thermotolerance when living inside the human body $[51,110,143]$. However, the opportunistic pathogen $C$. albicans resides on a host's skin and mucosal layers as a commensal yeast, while the hyphal form can penetrate host tissues and evade host immunity $[16,144]$. Moesziomyces aphidis, one of the Ustilaginomycotina species that exhibits promoted filamentous growth at high temperatures (Figures 1 and 2), has recently been found as the hyphal growth form in immunocompromised patients [145,146]. The entomopathogenic fungus Metarhizium rileyi switches to yeast-like growth upon entering the hemolymph of an insect. This helps the fungus spread throughout the host body. Once reaching a threshold critical density, it switches back, possibly by quorum-sensing, to the hyphal growth form to complete colonization and kill the host [42]. Many basidiomycete mycoparasites utilize the hyphal growth to penetrate host tissues and form a specialized structure called haustoria to absorb nutrients from the host [63]. However, their ecological roles during the saprobic yeast phase remains poorly studied.

For dimorphic plant pathogens, filamentous growth is a primary form that penetrates the epidermis and colonizes host tissues [147]. Genetic studies in U. maydis have shown that mutants with reduced filamentous growth often have attenuated virulence $[66,98,102,127,134]$. Although Tilletiopsis washingtonensis is a common yeast-like fungus typically recovered from leaf phylloplanes, it has recently been found producing extensive hyphal growth on apple skins, causing the postharvest disorder 'white haze' syndrome [58,148]. On the other hand, the yeast form can be beneficial for dissemination through plant vascular systems as shown in Ophiostoma and Verticillium [147]. Moreover, it is tempting to propose that the yeast form is more advantageous for passive dispersal through wind, rain or animal vectors. For example, Comeau et al. [149] suggested that the yeast form of Ophiostoma novo-ulmi is involved in passive dispersal of yeast-like budding spores to other elm trees through bark beetle vectors.

\section{Conclusions and Perspectives}

Fungal dimorphism is a sophisticated process that involves signal perception from multiple sources (environmental cues, cellular communication and host signals), reticulation of signal transduction (the cAMP/PKA pathway, the MAPK pathway and the GTPase-mediated pathway) and a complex regulatory network of gene expression. As the most extensively studied species, the corn smut fungus Ustilago maydis still serves as an excellent model for investigating fungal dimorphism and its role in pathogenic development. However, examination of non-model species is critical to understand which mechanisms are conserved and which are species-specific responses. For example, lipids and hydrophobicity, as common plant surface cues, appear to trigger yeast-to-hyphal transition in many plant-associated dimorphic fungi, with few exceptions. In addition, we show that data from mating gene studies and comparative genomics may not be enough to explain the difference in growth forms of these Ustilaginomycotina species. Integration of various approaches such as collection of more natural isolates, physiological screening and comparative transcriptomics are necessary for better understanding of this complex biological phenomenon.

According to our data, dimorphic transition is not an all-or-none response. For instance, some treatments promote filamentous growth of dimorphic fungi, but the proportion of filamentous cells is still lower than $50 \%$ (Figure 2). Several studies include only a few photomicrographs as a representation of growth form $[20,54,150]$. As the growth forms of dimorphic fungi are dynamic both in terms of cell population and time $[20,40,42]$, we strongly encourage the use of quantitative approaches, combined 
with statistical analyses, to support the findings as well as to determine the strength of phenotypes. Protocols used to distinguish yeast and filamentous cells should be clearly defined as these can be critical for result interpretation. Detailed methods have been described in systems like Candida albicans and Ophiostoma [39,41,151].

Defining 'dimorphic fungi' is often a challenging task, especially for less widely known species. One major reason is a lack of adequate observation. Many mycologists describe species based on their primary growth form observed in nature or in axenic culture. However, as dimorphic fungi may switch to another growth form only under certain conditions, they may be erroneously classified as either yeasts or filamentous fungi. For example, Moesziomyces aphidis was originally described as a yeast species with the presence of elongated cells resembling pseudohyphae [152], but recent studies show that it can grow as short hyphae $[146,153]$. Moreover, distinguishing between true hyphae and pseudohyphae is somewhat difficult unless their cytology is carefully investigated. Hence, an inclusive term 'filamentous growth' is often used to avoid any confusion. Finally, clear definitions for terms should be established. Some researchers define dimorphism as any yeast-like fungus that can undergo filamentous growth $[154,155]$, some limit the definition to only yeast-like fungi that form true hyphae as opposed to pseudohyphae [143], and some do not provide a clear distinction [156]. A new term, 'polymorphic fungi', has recently been applied for any fungi that can grow as yeasts, pseudohyphae and true hyphae $[143,156]$. Establishing clear definitions of terminology would facilitate the expansion of research in this area.

\section{Materials and Methods}

\subsection{Physiological Study}

The following strains were included in this study: Ustilago maydis TKC58 $\equiv$ NRRL Y-64004, Moeziomyces aphidis MCA6183 $\equiv$ NRRL Y-64005, Testicularia cyperi MCA3645 $\equiv$ ATCC MYA-4640, Violaceomyces palustris SA807 $\equiv$ CBS 139708, Meira miltonrushii MCA3882 $\equiv$ ATCC-MYA $4883 \equiv$ CBS 12591, Meira sp. MCA4637 $\equiv$ NRRL 66775, Acaromyces ingoldii MCA4198 $\equiv$ CBS 140884, Tilletiopsis washingtonensis MCA4186 $\equiv$ NRRL Y-63783, Jaminaea rosea MCA5214 $\equiv$ CBS 14051 and Pseudomicrostroma glucosiphilum MCA4718 $\equiv$ CBS14053.

We utilized Holliday's minimal liquid media [71] as the base media for the study. Carbon sources with $1 \%$ concentration $(w / v)$ were varied according to different treatments-glucose as a standard carbon source used in laboratory, sucrose as a representative for a mobilized carbon source in plants, soluble starch as a representative for a storage carbon source in plants, pectin as a representative for a structural carbohydrate of plant cell walls, and Tween 40 as a mimic of the waxy, hydrophobic surface of plants. For high temperature $\left(35^{\circ} \mathrm{C}\right)$ treatments we used $1 \%$ glucose $(w / v)$ as a carbon source. To set up an experiment, we cultured each fungal strain in yeast malt broth for 3 days. After that, cell suspensions were centrifuged and rinsed three times in sterile water. The number of $1 \times 10^{6}$ cells was inoculated into $5 \mathrm{~mL}$ of culture media, resulting in $2 \times 10^{5} \mathrm{cells} / \mathrm{mL}$ as an initial cell concentration. Most inoculated cells appeared as yeast growth, except $A$. ingoldii which appear as filamentous growth. There were five replicates for each treatment. The cultures were observed after five days of incubation at room temperature $\left(25^{\circ} \mathrm{C}\right)$, except the high temperature treatment at $35^{\circ} \mathrm{C}$, and $180 \mathrm{rpm}$ shaking condition.

To determine fungal growth forms, cell morphologies were observed under the BH-2 Olympus phase contrast microscope (Olympus Corp., Tokyo, Japan). For each sample, at least two hundred cells were counted and classified into two categories: yeast cells and filamentous cells. A cell bud was counted as one yeast cell, while an elongated fungal structure longer than two yeast cells without fungal cell wall constriction between cells was counted as filamentous cells. The Olympus SC30 camera was used to capture photomicrographs of fungal morphologies through the Olympus cellSens version 1.8 software. A percentage of filamentous cells was used as a proxy for types of growth form. We utilized $\mathrm{R}$ version 3.4.1 under RStudio version 1.0.153 for data analyses and visualization. Mean and standard deviation were reported for each treatment as a bar graph using the ggplot2 package [157]. One-way 
analysis of variance (ANOVA) was used to analyze difference in growth forms among treatments for each species; the Tukey's HSD test was used as a post-hoc comparison. $P$-values less than 0.01 were considered statistically significant.

\subsection{MAT Loci Studies}

Sixteen Ustilaginomycotina genomes were used in these analyses: Ustilago maydis [75], Sporisorium reilianum [76], Pseudozyma hubeiensis [77], Pseudozyma antarctica [78], Malassezia globosa [79], Malassezia sympodialis [80], Tilletiaria anomala [81], Exobasidium vaccinii [158], Acaromyces ingoldii, Ceraceosorus guamensis, Jaminaea rosea, Meira miltonrushii, Pseudomicrostroma glucosiphilum, Testicularia cyperi, Tilletiopsis washingtonensis and Violaceomyces palustris [13]. Genes in MAT loci were determined by blasting reference protein sequences from $U$. maydis genes against other species. The reference genes from $U$. maydis are as follows: Pra1 (UMAG_02383) for the MAT a locus, $b E$ (HD1, UMAG_00577) and $b W$ (HD2, UMAG_00578) for the MAT b locus. Once the MAT loci for each genome were identified, gene synteny was examined within 20 kilobases upstream and downstream of the mating genes. A pheromone precursor gene is sometimes unannotated due to its short gene length. Thus, we scanned with $20 \mathrm{~kb}$ upstream/downstream range from the pheromone receptor gene to confirm the presence/absence of the pheromone precursor gene using the FGENESH online portal with $U$. maydis as a reference (http://www.softberry.com/).

To analyze the MAT configuration within a phylogenetic context, protein sequences of the mating genes (pheromone receptor genes, $b E$, and $b W$ ) were used. The protein sequences of each gene were aligned using the MUSCLE algorithm performed in MEGA-X [159]. The alignments were visually inspected for any protein truncation. For the pheromone receptor genes, we incorporated additional reference protein sequences from $U$. maydis and $S$. reilianum to represent all three MAT $a$ alleles. The sequences, with GenBank accessions, are as follows: CAI59749 for the a1 allele in S. reilianum [67], P31303 for the $a 2$ allele in $U$. maydis [65] and CAI59763 for the $a 3$ allele in S. reilianum [67]. Finally, the aligned protein sequences of the pheromone receptor genes were used to reconstruct a phylogenetic tree through the Neighbor-joining method performed in MEGA-X with JTT as a protein substitution model and 1000-replicate bootstrapping as a node support value.

\subsection{Comparative Genomic Studies}

Sixteen Ustilaginomycotina genomes were used in the comparative genomic analyses. These include all genomes utilized in the mating gene studies, except Malassezia sympodialis, plus Moesziomyces aphidis [145]. We determined orthologous genes through OrthoFinder 2.1.2 [160] using protein models as inputs. Then, we selected only orthogroups containing $U$. maydis dimorphism genes (Table S1). Presence/absence patterns were indicated by non-zero/zero values of orthologs in each species. For orthogroups that have paralogs, we inspected a gene tree to determine gene orthologs. Any genes belonging to the same monophyletic clade as a reference gene were considered as true orthologs.

Supplementary Materials: The following are available online at http://www.mdpi.com/2309-608X/6/4/368/s1, Figure S1: Alignment of bE (HD1) protein sequences, Figure S2: Alignment of bW (HD2) protein, Figure S3: Gene phylogeny of pheromone receptors Pra1, Table S1: A list of known fungal dimorphism genes from Ustilago maydis literature.

Author Contributions: Conceptualization, T.K. and M.C.A.; methodology, T.K.; formal analysis, T.K.; investigation, T.K.; resources, M.C.A.; writing—original draft preparation, T.K.; writing-review and editing, T.K. and M.C.A.; visualization, T.K.; supervision, M.C.A.; funding acquisition, M.C.A. and T.K. All authors have read and agreed to the published version of the manuscript.

Funding: This research was funded by the USDA National Institute of Food and Agriculture Hatch project 1010662 granted to M.C.A. [grant number 1010662], and the Salomon Bartnicki-Garcia award from the Mycological Society of America granted to T.K.

Acknowledgments: We would like to acknowledge Michael Perlin, Barry Saville and Jan Schirawski for a kind invitation to publish our review article to this special issue of the Journal of Fungi. We thank Günther Doëhlemann from University of Cologne, Germany for granting us a permission to utilize the genome of Exobasidium vaccinii 
for our comparative analyses. T.K.'s study at Purdue University was financially supported by the Anandamahidol Foundation Scholarship, Thailand. This article is based in part on a dissertation submitted by T.K. to Purdue University as one requirement for a Ph.D. degree.

Conflicts of Interest: The authors declare no conflict of interest.

\section{References}

1. Zhao, Y.; Lin, J.; Fan, Y.; Lin, X. Life cycle of Cryptococcus neoformans. Annu. Rev. Microbiol. 2019, 73, 17-42. [CrossRef] [PubMed]

2. Riquelme, M.; Aguirre, J.; Bartnicki-García, S.; Braus, G.H.; Feldbrügge, M.; Fleig, U.; Hansberg, W.; Herrera-Estrella, A.; Kämper, J.; Kück, U.; et al. Fungal Morphogenesis, from the Polarized Growth of Hyphae to Complex Reproduction and Infection Structures. Microbiol. Mol. Biol. Rev. 2018, 82, 1-47. [CrossRef] [PubMed]

3. Kurtzman, C.P.; Sugiyama, J. Saccharomycotina and Taphrinomycotina: The Yeasts and Yeast-like Fungi of the Ascomycota. In The Mycota VII Systematics and Evolution Part B; McLaughlin, D.J., Spatafora, J.W., Eds.; Springer: Berlin/Heidelberg, Germany; New York, NY, USA, 2015; pp. 3-34.

4. Berkeley, M.J. On a confervoid state of Mucor clavatus, Lk. Mag. Zool. Bot. 1838, 2, 340-343.

5. Naranjo-Ortiz, M.A.; Gabaldón, T. Fungal evolution: Major ecological adaptations and evolutionary transitions. Biol. Rev. 2019. [CrossRef] [PubMed]

6. Sil, A.; Andrianopoulos, A. Thermally dimorphic human fungal pathogens-Polyphyletic pathogens with a convergent pathogenicity trait. Cold Spring Harb. Perspect. Med. 2015, 5, 1-17. [CrossRef] [PubMed]

7. Begerow, D.; Schaffer, A.M.; Kellner, R.; Youkov, A.; Kemler, M.; Oberwinkler, F.; Bauer, R. Ustilaginomycotina. In Mycota VII Systematics and Evolution Part A; McLaughlin, D.J., Spatafora, J.W., Eds.; Springer: Berlin/Heidelberg, Germany; New York, NY, USA, 2014; pp. 295-329.

8. Weiss, M.; Bauer, R.; Sampaio, J.P.; Oberwinkler, F. Tremellomycetes and Related Groups. In Mycota VII Systematics and Evolution Part A; McLaughlin, D.J., Spatafora, J.W., Eds.; Springer: Berlin/Heidelberg, Germany; New York, NY, USA, 2014; pp. 331-355.

9. Oberwinkler, F. Yeasts in Pucciniomycotina. Mycol. Prog. 2017, 16, 831-856. [CrossRef]

10. Vollmeister, E.; Schipper, K.; Baumann, S.; Haag, C.; Pohlmann, T.; Stock, J.; Feldbrügge, M. Fungal development of the plant pathogen Ustilago maydis. FEMS Microbiol. Rev. 2012, 36, 59-77. [CrossRef]

11. Hibbett, D.S.; Stajich, J.E.; Spatafora, J.W. Toward genome-enabled mycology. Mycologia 2013, 105, 1339-1349. [CrossRef]

12. Kijpornyongpan, T. Comparative Studies of Fungal Dimorphism in Dikarya; Purdue University: West Lafayette, IN, USA, 2019.

13. Kijpornyongpan, T.; Mondo, S.J.; Barry, K.; Sandor, L.; Lee, J.; Lipzen, A.; Pangilinan, J.; LaButti, K.; Hainaut, M.; Henrissat, B.; et al. Broad Genomic Sampling Reveals a Smut Pathogenic Ancestry of the Fungal Clade Ustilaginomycotina. Mol. Biol. Evol. 2018, 35, 1840-1854. [CrossRef]

14. Cullen, P.J.; Sprague, G.F. The regulation of filamentous growth in yeast. Genetics 2012, 190, 23-49. [CrossRef]

15. Amoah-Buahin, E.; Bone, N.; Armstrong, J. Hyphal Growth in the Fission Yeast. Microbiology 2005, 4, 1287-1297. [CrossRef]

16. Sudbery, P.E. Growth of Candida albicans hyphae. Nat. Rev. Microbiol. 2011, 9, 737-748. [CrossRef] [PubMed]

17. Lin, X. Cryptococcus neoformans: Morphogenesis, infection, and evolution. Infect. Genet. Evol. 2009, 9, 401-416. [CrossRef]

18. Paul, J.A.; Barati, M.T.; Cooper, M.; Perlin, H. Physical and Genetic Interaction between Ammonium Transporters and the Signaling Protein Rho1 in the Plant Pathogen Ustilago maydis. Eukaryot. Cell 2014, 13, 1328-1336. [CrossRef] [PubMed]

19. Yemelin, A.; Brauchler, A.; Jacob, S.; Laufer, J.; Heck, L.; Foster, A.J.; Antelo, L.; Andresen, K.; Thines, E. Identification of factors involved in dimorphism and pathogenicity of Zymoseptoria tritici. PLoS ONE 2017, 12, e0183065. [CrossRef] [PubMed]

20. Zhu, L.B.; Wang, Y.; Zhang, Z.B.; Yang, H.L.; Yan, R.M.; Zhu, D. Influence of environmental and nutritional conditions on yeast-Mycelial dimorphic transition in Trichosporon cutaneum. Biotechnol. Biotechnol. Equip. 2017, 2818. [CrossRef] 
21. Szabo, R. Dimorphism in Yarrowia lipolytica: Filament formation is suppressed by nitrogen starvation and inhibition of respiration. Folia Microbiol. (Praha) 1999, 44, 19-24. [CrossRef]

22. Park, D. Population density and yeast mycelial dimorphism in Aureobasidium pullulans. Trans. Br. Mycol. Soc. 1984, 82, 39-44. [CrossRef]

23. Kulkarni, R.K.; Nickerson, K.W. Nutritional control of dimorphism in Ceratocystis ulmi. Exp. Mycol. 1981, 5, 148-154. [CrossRef]

24. Ruiz-Herrera, J.; Sentandreu, R. Different effectors of dimorphism in Yarrowia lipolytica. Arch. Microbiol. 2002, 178, 477-483. [CrossRef]

25. Hou, L.; Chen, Y.; Ma, C.; Liu, J.; Chen, L.; Ma, A. Effects of environmental factors on dimorphic transition of the jelly mushroom Tremella fuciformis. Cryptogam. Mycol. 2011, 32, 421-428. [CrossRef]

26. Pippola, E.; Kyroviita, M.-M. Growth and dimorphism of the mycoparasite Tremella encephala as affected by different nitrogen and carbon sources and the host presence. Cryptogamie 2009, 30, 3.

27. Orlowski, M. Mucor Dimorphism. Microbiol. Rev. 1991, 55, 234-258. [CrossRef] [PubMed]

28. Cullen, P.J.; Sprague, G.F. Glucose depletion causes haploid invasive growth in yeast. Proc. Natl. Acad. Sci. USA 2000, 97, 13619-13624. [CrossRef]

29. Kim, J.; Cheon, S.A.; Park, S.; Song, Y.; Kim, J.Y. Serum-induced hypha formation in the dimorphic yeast Yarrowia lipolytica. FEMS Microbiol. Lett. 2000, 190, 9-12. [CrossRef]

30. Gilmore, S.A.; Naseem, S.; Konopka, J.B.; Sil, A. N-acetylglucosamine (GlcNAc) Triggers a Rapid, Temperature-Responsive Morphogenetic Program in Thermally Dimorphic Fungi. PLoS Genet. 2013, 9. [CrossRef]

31. Ruiz-Herrera, J.; Guevara-Olvera, C.G.L.L.; Cdrabez-Trejo, A. Yeast-mycelial dimorphism of haploid and diploid strains of Ustiago maydis. Microbiology 1995, 695-703. [CrossRef]

32. Buffo, J.; Herman, M.A.; Soll, D.R. A characterization of $\mathrm{pH}$-regulated dimorphism in Candida albicans. Mycopathologia 1984, 85, 21-30. [CrossRef]

33. Reeslev, M.; Jorgensen, B.B.; Jorgensen, O.B. Influence of $\mathrm{Zn}^{2+}$ on yeast-mycelium dimorphism and exopolysaccharide production by the fungus Aureobasidium pullulans grown in a defined medium in continuous culture. J. Gen. Microbiol. 1993, 139, 3065-3070. [CrossRef]

34. Schade, D.; Walther, A.; Wendland, J. The development of a transformation system for the dimorphic plant pathogen Holleya sinecauda based on Ashbya gossypii DNA elements. Fungal Genet. Biol. 2003, 40, 65-71. [CrossRef]

35. Keen, N.T.; Wang, M.C.; Long, M.; Erwin, D.C. Dimorphism in Verticillium albo-atrum as affected by initial spore concentration and antisporulant chemicals. Phytopathology 1971, 61, 1266-1269. [CrossRef]

36. Rodrigues, M.G.; Fonseca, A. Molecular systematics of the dimorphic ascomycete genus Taphrina. Int. J. Syst. Evol. Microbiol. 2003, 53, 607-616. [CrossRef] [PubMed]

37. Svetaz, L.A.; Bustamante, C.A.; Goldy, C.; Rivero, N.; Müller, G.L.; Valentini, G.H.; Fernie, A.R.; Drincovich, M.F.; Lara, M.V. Unravelling early events in the Taphrina deformans-Prunus persica interaction: An insight into the differential responses in resistant and susceptible genotypes. Plant Cell Environ. 2017, 40, 1456-1473. [CrossRef] [PubMed]

38. Maresca, B.; Lambowitz, A.M.; Kumar, V.B.; Grant, G.A.; Kobayashi, G.S.; Medoff, G. Role of cysteine in regulating morphogenesis and mitochondrial activity in the dimorphic fungus Histoplasma capsulatum. Proc. Natl. Acad. Sci. USA 1981, 78, 4596-4600. [CrossRef]

39. Hornby, J.M.; Jacobitz-Kizzier, S.M.; McNeel, D.J.; Jensen, E.C.; Treves, D.S.; Nickerson, K.W. Inoculum size effect in dimorphic fungi: Extracellular control of yeast-mycelium dimorphism in Ceratocystis ulmi. Appl. Environ. Microbiol. 2004, 70, 1356-1359. [CrossRef]

40. Naruzawa, E.S.; Bernier, L. Control of yeast-mycelium dimorphism invitro in Dutch elm disease fungi by manipulation of specific external stimuli. Fungal Biol. 2014, 118, 872-884. [CrossRef]

41. Naruzawa, E.S.; Malagnac, F.; Bernier, L. Effect of linoleic acid on reproduction and yeast-mycelium dimorphism in the Dutch elm disease pathogens. Botany 2016, 96, 31-39. [CrossRef]

42. Boucias, D.; Liu, S.; Meagher, R.; Baniszewski, J. Fungal dimorphism in the entomopathogenic fungus Metarhizium rileyi: Detection of an in vivo quorum-sensing system. J. Invertebr. Pathol. 2016, 136, 100-108. [CrossRef]

43. Hardcastle, R.V.; Szaniszlo, P.J. Characterization of dimorphism in Cladosporium werneckii. J. Bacteriol. 1974, 119, 294-302. [CrossRef] 
44. Houston, M.R.; Meyer, K.H.; Thomas, N.; Wolf, F.T. Dimorphism in Cladosporium werneckii. Sabouraudia J. Med. Vet. Mycol. 1969, 7, 195-198. [CrossRef]

45. Brefort, T.; Doehlemann, G.; Mendoza-mendoza, A.; Reissmann, S.; Djamei, A.; Kahmann, R. Ustilago maydis as a Pathogen. Annu. Rev. Phytopathol. 2009, 47, 423-445. [CrossRef] [PubMed]

46. Mendoza-Mendoza, A.; Berndt, P.; Djamei, A.; Weise, C.; Linne, U.; Marahiel, M.; Vraneš, M.; Kämper, J.; Kahmann, R. Physical-chemical plant-derived signals induce differentiation in Ustilago maydis. Mol. Microbiol. 2009, 71, 895-911. [CrossRef] [PubMed]

47. Youngchim, S.; Nosanchuk, J.D.; Pornsuwan, S.; Kajiwara, S.; Vanittanakom, N. The role of L-DOPA on melanization and mycelial production in Malassezia furfur. PLoS ONE 2013, 8, e63764. [CrossRef] [PubMed]

48. Faergemann, J.; Bernander, S. Micro-aerophilic and anaerobic growth of Pityrosporum species. Med. Mycol. 1981, 19, 117-121. [CrossRef]

49. Faergemann, J. A new model for growth and filament production of Pityrosporum ovale (orbiculare) on human stratum corneum in vitro. J. Investig. Dermatol. 1989, 92, 117-119. [CrossRef]

50. Schäfer, A.M.; Kemler, M.; Bauer, R.; Begerow, D. The illustrated life cycle of Microbotryum on the host plant Silene latifolia. Botany 2010, 88, 875-885. [CrossRef]

51. Morrow, C.A.; Fraser, J.A. Sexual reproduction and dimorphism in the pathogenic basidiomycetes. FEMS Yeast Res. 2009, 9, 161-177. [CrossRef]

52. Lanver, D.; Mendoza-Mendoza, A.; Brachmann, A.; Kahmann, R. Sho1 and Msb2-related proteins regulate appressorium development in the smut fungus Ustilago maydis. Plant Cell 2010, 22, 2085-2101. [CrossRef]

53. Domínguez, E.; Cuartero, J.; Heredia, A. An overview on plant cuticle biomechanics. Plant Sci. 2011, 181,77-84. [CrossRef]

54. Klose, J.; De Sá, M.M.; Kronstad, J.W. Lipid-induced filamentous growth in Ustilago maydis. Mol. Microbiol. 2004, 52, 823-835. [CrossRef]

55. Rush, T.A.; Aime, M.C. The genus Meira: Phylogenetic placement and description of a new species. Antonie Van Leeuwenhoek 2013, 103, 1097-1106. [CrossRef] [PubMed]

56. Kijpornyongpan, T.; Aime, M.C. Taxonomic revisions in the Microstromatales: Two new yeast species, two new genera, and validation of Jaminaea and two Sympodiomycopsis species. Mycol. Prog. 2017, 16, 495-505. [CrossRef]

57. Albu, S.; Toome, M.; Aime, M.C. Violaceomyces palustris gen. et sp. nov. and a new monotypic lineage, Violaceomycetales ord. nov. in Ustilaginomycetes. Mycologia 2015, 107, 1193-1204. [CrossRef] [PubMed]

58. Boekhout, T.; Gildemacher, P.; Theelen, B.; Müller, W.H.; Heijne, B.; Lutz, M. Extensive colonization of apples by smut anamorphs causes a new postharvest disorder. FEMS Yeast Res. 2006, 6, 63-76. [CrossRef] [PubMed]

59. Liu, W.; Zhou, X.; Li, G.; Li, L.; Kong, L.; Wang, C.; Zhang, H.; Xu, J.R. Multiple plant surface signals are sensed by different mechanisms in the rice blast fungus for appressorium formation. PLoS Pathog. 2011, 7. [CrossRef] [PubMed]

60. Zabka, V.; Stangl, M.; Bringmann, G.; Vogg, G.; Riederer, M.; Hildebrandt, U. Host surface properties affect prepenetration processes in the barley powdery mildew fungus. New Phytol. 2008, 177, 251-263. [CrossRef]

61. Borges-Walmsley, M.I.; Walmsley, A.R. cAMP signalling in pathogenic fungi: Control of dimorphic switching and pathogenicity. Trends Microbiol. 2000, 8, 133-141. [CrossRef]

62. Wongsuk, T.; Pumeesat, P.; Luplertlop, N. Fungal quorum sensing molecules: Role in fungal morphogenesis and pathogenicity. J. Basic Microbiol. 2016, 56, 440-447. [CrossRef]

63. Boekhout, T.; Fonseca, A.; Sampaio, J.P.; Bandoni, R.J.; Fell, J.W.; Kwon-Chung, K.J. Discussion of Teleomorphic and Anamorphic Basidiomycetous Yeasts. In The Yeasts, a Taxonomic Study Volume 3; Kurtzman, C.P., Fell, J.W., Boekhout, T., Eds.; Elseiver: Burlington, MA, USA, 2011; pp. 1339-1371.

64. Spellig, T.; Bölker, M.; Lottspeich, F.; Frank, R.W.; Kahmann, R. Pheromones trigger filamentous growth in Ustilago maydis. EMBO J. 1994, 13, 1620-1627. [CrossRef]

65. Bölker, M.; Urban, M.; Kahmann, R. The $a$ mating type locus of $U$. maydis specifies cell signaling components. Cell 1992, 68, 441-450. [CrossRef]

66. Hartmann, H.A.; Kahmann, R.; Bolker, M. The pheromone response factor coordinates filamentous growth and pathogenicity in Ustilago maydis. Embo J. 1996, 15, 1632-1641. [CrossRef]

67. Schirawski, J.; Heinze, B.; Wagenknecht, M.; Kahmann, R. Mating type loci of Sporisorium reilianum: Novel pattern with three a and multiple b specificities. Eukaryot. Cell 2005, 4, 1317-1327. [CrossRef] 
68. Yan, M.; Zhu, G.; Lin, S.; Xian, X.; Chang, C.; Xi, P.; Shen, W.; Huang, W.; Cai, E.; Jiang, Z.; et al. The mating-type locus $b$ of the sugarcane smut Sporisorium scitamineum is essential for mating, filamentous growth and pathogenicity. Fungal Genet. Biol. 2016, 86, 1-8. [CrossRef]

69. Kües, U.; James, T.; Heitman, J. Mating Type in Basidiomycetes: Unipolar, Bipolar, and Tetrapolar Patterns of Sexuality. Evol. Fungi Fungal-Like Org. 2011, 14, 97-160. [CrossRef]

70. Sabbagh, S.K.; Diagne-Lèye, G.; Naudan, M.; Roux, C.P. Solopathogenic strain formation strongly differs among Ustilaginaceae species. FEMS Microbiol. Lett. 2010, 305, 121-127. [CrossRef]

71. Holliday, R. Ustilago maydis . In Handbook of Genetics, Vol. 1. Bacteria, Bacteriophages and Fungi; King, R.C., Ed.; Springer: Plenum, NY, USA, 1997; pp. 575-595.

72. Bölker, M.; Genin, S.; Lehmler, C.; Kahmann, R. Genetic regulation of mating and dimorphism in Ustilago maydis. Can. J. Bot. 1995, 73, 320-325. [CrossRef]

73. Billiard, S.; López-Villavicencio, M.; Devier, B.; Hood, M.E.; Fairhead, C.; Giraud, T. Having sex, yes, but with whom? Inferences from fungi on the evolution of anisogamy and mating types. Biol. Rev. 2011, 86, 421-442. [CrossRef]

74. Kellner, R.; Vollmeister, E.; Feldbrügge, M.; Begerow, D. Interspecific sex in grass smuts and the genetic diversity of their pheromone-receptor system. PLoS Genet. 2011, 7. [CrossRef]

75. Kämper, J.; Kahmann, R.; Bölker, M.; Ma, L.-J.; Brefort, T.; Saville, B.J.; Banuett, F.; Kronstad, J.W.; Gold, S.E.; Müller, O.; et al. Insights from the genome of the biotrophic fungal plant pathogen Ustilago maydis. Nature 2006, 444, 97-101. [CrossRef]

76. Schirawski, J.; Mannhaupt, G.; Münch, K.; Brefort, T.; Schipper, K.; Doehlemann, G.; Di Stasio, M.; Rössel, N.; Mendoza-Mendoza, A.; Pester, D.; et al. Pathogenicity determinants in smut fungi revealed by genome comparison. Science 2010, 330, 1546-1548. [CrossRef]

77. Konishi, M.; Hatada, Y.; Horiuchi, J.-I. Draft Genome Sequence of the Basidiomycetous Yeast-Like Fungus Pseudozyma hubeiensis SY62, Which Produces an Abundant Amount of the Biosurfactant Mannosylerythritol Lipids. Genome Announc. 2013, 1, e00409-13. [CrossRef]

78. Morita, T.; Koike, H.; Koyama, Y.; Hagiwara, H.; Ito, E.; Fukuoka, T.; Imura, T.; Machida, M.; Kitamoto, D. Genome sequence of the basidiomycetous yeast Pseudozyma antarctica T-34, a producer of the glycolipid biosurfactants mannosylerythritol lipids. Genome Announc. 2013, 1, e00064-13. [CrossRef]

79. Xu, J.; Saunders, C.W.; Hu, P.; Grant, R.A.; Boekhout, T.; Kuramae, E.E.; Kronstad, J.W.; Deangelis, Y.M.; Reeder, N.L.; Johnstone, K.R.; et al. Dandruff-associated Malassezia genomes reveal convergent and divergent virulence traits shared with plant and human fungal pathogens. Proc. Natl. Acad. Sci. USA 2007, 104, 18730-18735. [CrossRef]

80. Gioti, A.; Nystedt, B.; Li, W. Genomic Insights into the Atopic Eczema-Associated Skin Commensal Yeast Malassezia sympodialis. MBio 2013, 4, 1-16. [CrossRef]

81. Toome, M.; Kuo, A.; Henrissat, B.; Lipzen, A.; Tritt, A.; Yoshinaga, Y.; Zane, M.; Barry, K.; Grigoriev, I.V.; Spatafora, J.W.; et al. Draft Genome Sequence of a Rare Smut Relative, Tilletiaria anomala UBC 951. Genome Announc. 2014, 2, 2-3. [CrossRef]

82. Hamel, L.-P.; Nicole, M.-C.; Duplessis, S.; Ellis, B.E. Mitogen-Activated Protein Kinase Signaling in Plant-Interacting Fungi: Distinct Messages from Conserved Messengers. Plant Cell 2012, 24, 1327-1351. [CrossRef]

83. Fuller, K.K.; Rhodes, J.C. Protein kinase A and fungal virulence A sinister side to a conserved nutrient sensing pathway. Virulence 2012, 3, 109-121. [CrossRef]

84. Regenfelder, E.; Spellig, T.; Hartmann, A.; Lauenstein, S.; Bölker, M.; Kahmann, R. G proteins in Ustilago maydis: Transmission of multiple signals? EMBO J. 1997, 16, 1934-1942. [CrossRef]

85. Müller, P.; Leibbrandt, A.; Teunissen, H.; Cubasch, S.; Aichinger, C.; Kahmann, R. The G $\beta$-subunit-encoding gene bpp1 controls cyclic-AMP signaling in Ustilago maydis. Eukaryot. Cell 2004, 3, 806-814. [CrossRef]

86. Gold, S.; Duncan, G.; Barrett, K.; Kronstad, J. cAMP regulates morphogenesis in the fungal pathogen Ustilago maydis. Genes Dev. 1994, 8, 2805-2816. [CrossRef]

87. Gold, S.E.; Brogdon, S.M.; Mayorga, M.E.; Kronstad, J.W. The Ustilago maydis regulatory subunit of a cAMP-dependent protein kinase is required for gall formation in maize. Plant Cell 1997, 9, 1585-1594.

88. Dürrenberger, F.; Wong, K.; Kronstad, J.W. Identification of a cAMP-dependent protein kinase catalytic subunit required for virulence and morphogenesis in Ustilago maydis. Proc. Natl. Acad. Sci. USA 1998, 95, 5684-5689. [CrossRef] 
89. Agarwal, C.; Aulakh, K.B.; Edelen, K.; Cooper, M.; Wallen, R.M.; Adams, S.; Schultz, D.J.; Perlin, M.H. Ustilago maydis phosphodiesterases play a role in the dimorphic switch and in pathogenicity. Microbiology 2013, 159, 857-868. [CrossRef]

90. Krüger, J.; Loubradou, G.; Regenfelder, E.; Hartmann, A.; Kahmann, R. Crosstalk between cAMP and pheromone signalling pathways in Ustilago maydis. Mol. Gen. Genet. 1998, 260, 193-198. [CrossRef]

91. Martínez-Espinoza, A.D.; Ruiz-Herrera, J.; León-Ramírez, C.G.; Gold, S.E. MAP kinase and cAMP signaling pathways modulate the $\mathrm{pH}$-induced yeast-to-mycelium dimorphic transition in the corn smut fungus Ustilago maydis. Curr. Microbiol. 2004, 49, 274-281. [CrossRef]

92. Müller, P.; Weinzierl, G.; Brachmann, A.; Feldbrügge, M.; Kahmann, R. Mating and pathogenic development of the smut fungus Ustilago maydis are regulated by one mitogen-activated protein kinase cascade. Eukaryot. Cell 2003, 2, 1187-1199. [CrossRef]

93. Andrews, D.L.; Egan, J.D.; Mayorga, M.E.; Gold, S.E. The Ustilago maydis ubc4 and ubc5 genes encode members of a MAP kinase cascade required for filamentous growth. Mol. Plant-Microbe Interact. 2000, 13, 781-786. [CrossRef]

94. Banuett, F.; Herskowitz, I. Identification of fuz7, a Ustilago maydis MEK/MAPKK homolog required for a-locus-dependent and-independent steps in the fungal life cycle. Genes Dev. 1994, 8, 1367-1378. [CrossRef] [PubMed]

95. Müller, P.; Aichinger, C.; Feldbrügge, M.; Kahmann, R. The MAP kinase kpp2 regulates mating and pathogenic development in Ustilago maydis. Mol. Microbiol. 1999, 34, 1007-1017. [CrossRef]

96. Mayorga, M.E.; Gold, S.E. A MAP kinase encoded by the ubc3 gene of Ustilago maydis is required for filamentous growth and full virulence. Mol. Microbiol. 1999, 34, 485-497. [CrossRef]

97. Brachmann, A.; Schirawski, J.; Müller, P.; Kahmann, R. An unusual MAP kinase is required for efficient penetration of the plant surface by Ustilago maydis. EMBO J. 2003, 22, 2199-2210. [CrossRef] [PubMed]

98. Garrido, E.; Voß, U.; Müller, P.; Castillo-lluva, S.; Kahmann, R. The induction of sexual development and virulence in the smut fungus Ustilago maydis depends on Crk1, a novel MAPK protein. Genes Dev. 2004, 7, 3117-3130. [CrossRef] [PubMed]

99. Klosterman, S.J.; Martinez-Espinoza, A.D.; Andrews, D.L.; Seay, J.R.; Gold, S.E. Ubc2, an ortholog of the yeast Ste50p adaptor, possesses a basidiomycete-specific carboxy terminal extension essential for pathogenicity independent of pheromone response. Mol. Plant-Microbe Interact. 2008, 21, 110-121. [CrossRef] [PubMed]

100. Mayorga, M.E.; Gold, S.E. The ubc2 gene of Ustilago maydis encodes a putative novel adaptor protein required for filamentous growth, pheromone response and virulence. Mol. Microbiol. 2001, 41, 1365-1379. [CrossRef]

101. Di Stasio, M.; Brefort, T.; Mendoza-Mendoza, A.; Münch, K.; Kahmann, R. The dual specificity phosphatase Rok1 negatively regulates mating and pathogenicity in Ustilago maydis. Mol. Microbiol. 2009, 73, 73-88. [CrossRef]

102. Garrido, E.; Pérez-Martín, J. The crk1 gene encodes an ime2-related protein that is required for morphogenesis in the plant pathogen Ustilago maydis. Mol. Microbiol. 2003, 47, 729-743. [CrossRef]

103. Strudwick, N.; Brown, M.; Parmar, V.M.; Schroder, M. Ime1 and Ime2 Are Required for Pseudohyphal Growth of Saccharomyces cerevisiae on Nonfermentable Carbon Sources. Mol. Cell. Biol. 2010, 30, 5514-5530. [CrossRef]

104. Lee, N.; Kronstad, J.W. ras2 controls morphogenesis, pheromone response, and pathogenicity in the fungal pathogen Ustilago maydis. Eukaryot. Cell 2002, 1, 954-966. [CrossRef]

105. Müller, P.; Katzenberger, D.; Loubradou, G.; Kahmann, R. Guanyl Nucleotide Exchange Factor Sql2 and Ras2 Regulate Filamentous Growth in Ustilago maydis. Eukaryot. Cell 2003, 2, 609-617. [CrossRef]

106. Mahlert, M.; Leveleki, L.; Hlubek, A.; Sandrock, B.; Bölker, M. Rac1 and Cdc42 regulate hyphal growth and cytokinesis in the dimorphic fungus Ustilago maydis. Mol. Microbiol. 2006, 59, 567-578. [CrossRef]

107. Pham, C.D.; Yu, Z.; Bolker, M.; Gold, S.E.; Perlin, M.H. Ustilago maydis Rho1 and 14-3-3 Homologues Participate in Pathways Controlling Cell Separation and Cell Polarity. Eukaryot. Cell 2009, 8, 977-989. [CrossRef] [PubMed]

108. Leveleki, L.; Mahlert, M.; Sandrock, B.; Bölker, M. The PAK family kinase Cla4 is required for budding and morphogenesis in Ustilago maydis. Mol. Microbiol. 2004, 54, 396-406. [CrossRef] [PubMed]

109. Castillo-Lluva, S.; Alvarez-Tabares, I.; Weber, I.; Steinberg, G.; Perez-Martin, J. Sustained cell polarity and virulence in the phytopathogenic fungus Ustilago maydis depends on an essential cyclin-dependent kinase from the Cdk5/Pho85 family. J. Cell Sci. 2007, 120, 1584-1595. [CrossRef] [PubMed] 
110. Boyce, K.J.; Andrianopoulos, A. Fungal dimorphism: The switch from hyphae to yeast is a specialized morphogenetic adaptation allowing colonization of a host. FEMS Microbiol. Rev. 2015, 39, 797-811. [CrossRef] [PubMed]

111. Campos, C.B.L.; Di Benedette, J.P.T.; Morais, F.V.; Ovalle, R.; Nobrega, M.P. Evidence for the role of calcineurin in morphogenesis and calcium homeostasis during mycelium-to-yeast dimorphism of Paracoccidioides brasiliensis. Eukaryot. Cell 2008, 7, 1856-1864. [CrossRef] [PubMed]

112. Lee, S.C.; Li, A.; Calo, S.; Heitman, J. Calcineurin Plays Key Roles in the Dimorphic Transition and Virulence of the Human Pathogenic Zygomycete Mucor circinelloides. PLoS Pathog. 2013, 9. [CrossRef]

113. Lee, S.C.; Li, A.; Calo, S.; Inoue, M.; Tonthat, N.K.; Bain, J.M.; Louw, J.; Shinohara, M.L.; Erwig, L.P.; Schumacher, M.A.; et al. Calcineurin orchestrates dimorphic transitions, antifungal drug responses and host-Pathogen interactions of the pathogenic mucoralean fungus Mucor circinelloides. Mol. Microbiol. 2015, 97, 844-865. [CrossRef]

114. Egan, J.D.; García-pedrajas, M.D.; Andrews, D.L.; Gold, S.E. Calcineurin Is an Antagonist to PKA Protein Phosphorylation Required for Postmating Filamentation and Virulence, While PP2A Is Required for Viability in Ustilago maydis. Mol. Plant-Microbe Interact. 2009, 22, 1293-1301. [CrossRef]

115. Paul, J.A.; Wallen, R.M.; Zhao, C.; Shi, T.; Perlin, M.H. Coordinate regulation of Ustilago maydis ammonium transporters and genes involved in mating and pathogenicity. Fungal Biol. 2018, 122, 639-650. [CrossRef]

116. Brefort, T.; Müller, P.; Kahmann, R. The high-mobility-group domain transcription factor Rop1 is a direct regulator of prf1 in Ustilago maydis. Eukaryot. Cell 2005, 4, 379-391. [CrossRef]

117. Hartmann, H.A.; Krüger, J.; Lottspeich, F.; Kahmann, R. Environmental signals controlling sexual development of the corn smut fungus Ustilago maydis through the transcriptional regulator Prf1. Plant Cell 1999, 11, 1293-1305. [CrossRef]

118. Elías-Villalobos, A.; Fernández-Álvarez, A.; Ibeas, J.I. The general transcriptional repressor Tup1 is required for dimorphism and virulence in a fungal plant pathogen. PLoS Pathog. 2011, 7, e1002235. [CrossRef]

119. Chacko, N.; Gold, S. Deletion of the Ustilago maydis ortholog of the Aspergillus sporulation regulator medA affects mating and virulence through pheromone response. Fungal Genet. Biol. 2012, 49, 426-432. [CrossRef]

120. Wang, L.; Berndt, P.; Xia, X.; Kahnt, J.; Kahmann, R. A seven-WD40 protein related to human RACK1 regulates mating and virulence in Ustilago maydis. Mol. Microbiol. 2011, 81, 1484-1498. [CrossRef]

121. Elías-Villalobos, A.; Fernández-Alvarez, A.; Moreno-Sánchez, I. The Hos2 Histone Deacetylase Controls Ustilago maydis Virulence through Direct Regulation of Mating-Type Genes. PLoS Pathog. 2015, 11, e1005134. [CrossRef]

122. Kaffarnik, F.; Müller, P.; Leibundgut, M.; Kahmann, R.; Feldbrügge, M. PKA and MAPK phosphorylation of Prf1 allows promoter discrimination in Ustilago maydis. EMBO J. 2003, 22, 5817-5826. [CrossRef]

123. Brachmann, A.; Weinzierl, G. Identification of genes in the bW/bE regulatory cascade in Ustilago maydis. Mol. Microbiol. 2001, 42, 1047-1063. [CrossRef]

124. Heimel, K.; Scherer, M.; Vranes, M.; Wahl, R.; Pothiratana, C.; Schuler, D.; Vincon, V.; Finkernagel, F.; Flor-Parra, I.; Kämper, J. The Transcription Factor Rbf1 Is the Master Regulator for b-Mating Type Controlled Pathogenic Development in Ustilago maydis. PLOS Pathog. 2010, 6, e1001035. [CrossRef]

125. Tollot, M.; Assmann, D.; Becker, C.; Altmüller, J. The WOPR Protein Ros1 Is a Master Regulator of Sporogenesis and Late Effector Gene Expression in the Maize Pathogen Ustilago maydis. PLoS Pathog. 2016, 12, e1005697. [CrossRef]

126. Dürrenberger, F.; Laidlaw, R.D.; Kronstad, J.W. The hgl1 gene is required for dimorphism and teliospore formation in the fungal pathogen Ustilago maydis. Mol. Microbiol. 2001, 41, 337-348. [CrossRef]

127. Horst, R.J.; Zeh, C.; Saur, A.; Sonnewald, S.; Sonnewald, U.; Voll, L.M. The Ustilago maydis Nit2 Homolog Regulates Nitrogen Utilization and Is Required for Efficient Induction of Filamentous Growth. Eukaryot. Cell 2012, 11, 368-380. [CrossRef]

128. González-prieto, J.M.; Rosas-quijano, R.; Domínguez, A.; Ruiz-herrera, J. The UmGcn5 gene encoding histone acetyltransferase from Ustilago maydis is involved in dimorphism and virulence. Fungal Genet. Biol. 2014, 71, 86-95. [CrossRef]

129. Weber, I.; Gruber, C.; Steinberg, G. A class-V myosin required for mating, hyphal growth, and pathogenicity in the dimorphic plant pathogen Ustilago maydis. Plant Cell 2003, 15, 2826-2842. [CrossRef] 
130. Steinberg, G.; Schliwa, M.; Lehmler, C.; Bolker, M.; Kahmann, R.; McIntosh, J.R. Kinesin from the plant pathogenic fungus Ustilago maydis is involved in vacuole formation and cytoplasmic migration. J. Cell Sci. 1998, 111, 2235-2246.

131. Schuchardt, I.; Aßmann, D.; Thines, E.; Schuberth, C.; Steinberg, G. Myosin-V, Kinesin-1, and Kinesin-3 cooperate in hyphal growth of the fungus Ustilago maydis. Mol. Biol. Cell 2005, 16, 5191-5201. [CrossRef]

132. Weber, I.; Thines, E.; Steinberg, G. Polar Localizing Class V Myosin Chitin Synthases Are Essential during Early Plant Infection in the Plant Pathogenic Fungus Ustilago maydis. Plant Cell 2006, 18, 225-242. [CrossRef]

133. García-Muse, T.; Steinberg, G.; Pérez-Martín, J. Characterization of B-type cyclins in the smut fungus Ustilago maydis: Roles in morphogenesis and pathogenicity. J. Cell Sci. 2004, 117, 487-506. [CrossRef]

134. Boyce, K.J.; Chang, H.; D'Souza, C.A.; Kronstad, J.W. An Ustilago maydis septin is required for filamentous growth in culture and for full symptom development on maize. Eukaryot. Cell 2005, 4, 2044-2056. [CrossRef]

135. Scherer, M.; Heimel, K.; Starke, V.; Kämper, J. The Clp1 Protein Is Required for Clamp Formation and Pathogenic Development of Ustilago maydis. Plant Cell 2006, 18, 2388-2401. [CrossRef]

136. Wedlich-Söldner, R.; Bölker, M.; Kahmann, R.; Steinberg, G. A putative endosomal t-SNARE links exo-and endocytosis in the phytopathogenic fungus Ustilago maydis. EMBO J. 2000, 19, 1974-1986. [CrossRef]

137. Valinluck, M.; Woraratanadharm, T.; Lu, C.Y.; Quintanilla, R.H.; Banuett, F. The cell end marker Tea4 regulates morphogenesis and pathogenicity in the basidiomycete fungus Ustilago maydis. Fungal Genet. Biol. 2014, 66, 54-68. [CrossRef]

138. Woraratanadharm, T.; Kmosek, S.; Banuett, F. UmTea1, a Kelch and BAR domain-containing protein, acts at the cell cortex to regulate cell morphogenesis in the dimorphic fungus Ustilago maydis. Fungal Genet. Biol. 2018, 121, 10-28. [CrossRef]

139. Becht, P.; Vollmeister, E.; Feldbrügge, M. Role for RNA-Binding Proteins Implicated in Pathogenic Development of Ustilago maydis. Eukaryot. Cell 2005, 4, 121-133. [CrossRef]

140. Vollmeister, E.; Haag, C.; Zarnack, K.; Baumann, S.; König, J.; Mannhaupt, G.; Feldbrügge, M. Tandem KH domains of Khd4 recognize AUACCC and are essential for regulation of morphology as well as pathogenicity in Ustilago maydis. RNA 2009, 15, 2206-2218. [CrossRef]

141. Becht, P.; König, J.; Feldbrügge, M. The RNA-binding protein Rrm4 is essential for polarity in Ustilago maydis and shuttles along microtubules. J. Cell Sci. 2006, 119, 4964-4973. [CrossRef]

142. Lorenz, S.; Guenther, M.; Grumaz, C.; Rupp, S.; Zibek, S.; Sohn, K. Genome sequence of the basidiomycetous fungus Pseudozyma aphidis DSM70725, an efficient producer of biosurfactant mannosylerythritol lipids. Genome Announc. 2014, 2, e00053-14. [CrossRef]

143. Gauthier, G.M. Dimorphism in Fungal Pathogens of Mammals, Plants, and Insects. PLoS Pathog. 2015, 11, e1004608. [CrossRef]

144. Noble, S.M.; Gianetti, B.A.; Witchley, J.N. Candida albicans cell-type switching and functional plasticity in the mammalian host. Nat. Rev. Microbiol. 2017, 15, 96-108. [CrossRef]

145. Joo, H.; Choi, Y.; Cho, S.; Choi, J.; Lee, D.; Kim, H.; Jo, I.; Park, Y.; Lee, K. Pseudozyma aphidis fungaemia with invasive fungal pneumonia in a patient with acute myeloid leukaemia: Case report and literature review. Mycoses 2016, 59, 56-61. [CrossRef]

146. Herb, A.; Sabou, M.; Delhorme, J.-B.; Pessaux, P.; Mutter, D.; Candolfi, E.; Letscher-Bru, V. Pseudozyma aphidis fungemia after abdominal surgery: First adult case. Med. Mycol. Case Rep. 2015, 8, 37-39. [CrossRef]

147. Nadal, M.; García-Pedrajas, M.D.; Gold, S.E. Dimorphism in fungal plant pathogens. FEMS Microbiol. Lett. 2008, 284, 127-134. [CrossRef] [PubMed]

148. Baric, S.; Lindner, L.; Marschall, K.; Dalla Via, J. Haplotype diversity of Tilletiopsis spp. causing white haze in apple orchards in Northern Italy. Plant Pathol. 2010, 59, 535-541. [CrossRef]

149. Comeau, A.M.; Dufour, J.; Bouvet, G.F.; Jacobi, V.; Nigg, M.; Henrissat, B.; Laroche, J.; Levesque, R.C.; Bernier, L. Functional annotation of the Ophiostoma novo-ulmi genome: Insights into the phytopathogenicity of the fungal agent of Dutch elm disease. Genome Biol. Evol. 2015, 7, 410-430. [CrossRef] [PubMed]

150. Wanchoo, A.; Lewis, M.W.; Keyhani, N.O. Lectin mapping reveals stage-specific display of surface carbohydrates in in vitro and haemolymph- derived cells of the entomopathogenic fungus Beauveria bassiana. Microbiology 2009, 155, 3121-3133. [CrossRef]

151. Manning, M.; Mitchell, T.G. Strain variation and morphogenesis of yeast- and mycelial-phase Candida albicans in low-sulfate, synthetic medium. J. Bacteriol. 1980, 142, 714-719. [CrossRef] 
152. Henninger, W.; Windisch, S. A New Yeast of Sterigmatomyces, S. aphidis sp. nov. Arch. Microbiol. 1975, 105, 49-50. [CrossRef]

153. Boekhout, T. Pseudozyma Bandoni emend. for yeast-like anamorphs of Ustilaginales. J. Gen. Appl. Microbiol. 1995, 41, 359-366. [CrossRef]

154. Doiphode, N.; Joshi, C.; Ghormade, V.; Deshpande, M. V Biotechnological Applications of Dimorphic Yeasts. In Yeast Biotechnology: Diversity and Applications; Satyanarayana, T., Kunze, G., Eds.; Springer: Berlin/Heidelberg, Germany, 2009; pp. 635-650.

155. Ceccato-antonini, S.R.; Sudbery, P.E. Filamentous Growth in Saccharomyces cerevisiae. Braz. J. Microbiol. 2004, 35, 173-181. [CrossRef]

156. Ruiz-herrera, J.; Campos-Góngora, E. An Introduction to Fungal Dimorphism. In Dimorphic Fungi: Their Importance as Models for Differentiation and Fungal Pathogenesis; Ruiz-herrera, J., Ed.; Bentham Science: Sharjah, UAE, 2012; pp. 3-15.

157. Doëhlemann, G. Exobasidium vaccinii MPITM Genome sequencing. unpublished.

158. Wickham, H. ggplot2: Elegant Graphics for Data Analysis; Springer: Berlin/Heidelberg, Germany, 2016; ISBN 3319242776.

159. Kumar, S.; Stecher, G.; Li, M.; Knyaz, C.; Tamura, K. MEGA X: Molecular evolutionary genetics analysis across computing platforms. Mol. Biol. Evol. 2018, 35, 1547-1549. [CrossRef]

160. Emms, D.M.; Kelly, S. OrthoFinder: Solving fundamental biases in whole genome comparisons dramatically improves orthogroup inference accuracy. Genome Biol. 2015, 16, 157. [CrossRef]

Publisher's Note: MDPI stays neutral with regard to jurisdictional claims in published maps and institutional affiliations.

(C) 2020 by the authors. Licensee MDPI, Basel, Switzerland. This article is an open access article distributed under the terms and conditions of the Creative Commons Attribution (CC BY) license (http://creativecommons.org/licenses/by/4.0/). 